\title{
WestVirginiaUniversity
}

THE RESEARCH REPOSITORY @ WVU

Graduate Theses, Dissertations, and Problem Reports

2006

\section{Willingness to pay as a predictor of viability for three different recreational pass variables}

Jessica Ann Neff

West Virginia University

Follow this and additional works at: https://researchrepository.wvu.edu/etd

\section{Recommended Citation}

Neff, Jessica Ann, "Willingness to pay as a predictor of viability for three different recreational pass variables" (2006). Graduate Theses, Dissertations, and Problem Reports. 2366.

https://researchrepository.wvu.edu/etd/2366

This Thesis is protected by copyright and/or related rights. It has been brought to you by the The Research Repository @ WVU with permission from the rights-holder(s). You are free to use this Thesis in any way that is permitted by the copyright and related rights legislation that applies to your use. For other uses you must obtain permission from the rights-holder(s) directly, unless additional rights are indicated by a Creative Commons license in the record and/ or on the work itself. This Thesis has been accepted for inclusion in WVU Graduate Theses, Dissertations, and Problem Reports collection by an authorized administrator of The Research Repository @ WVU. For more information, please contact researchrepository@mail.wvu.edu. 
Willingness to Pay as a Predictor of Viability for

Three Different Recreational Pass Variables

\author{
Jessica Ann Neff
}

Thesis submitted to the Davis College of Agriculture, Forestry, and Consumer Sciences at West Virginia University in partial fulfillment of the requirements for the degree of

\author{
Master of Science \\ in \\ Recreation, Parks, and Tourism Resources
}

Robert C. Burns, Ph.D., Chair

Chad D. Pierskalla, Ph.D.

David Smaldone, Ph.D.

Division of Forestry and Natural Resources

Morgantown, West Virginia

2006

Keywords: Recreation Fee Program, Willingness to Pay 


\begin{abstract}
Willingness to Pay as a Predictor of Viability for Three Different Recreational Pass Variables
\end{abstract}

Jessica A. Neff

In 1996, under the Clinton administration, the recreation fee demonstration program (RFDP) was authorized by Congress as a three-year pilot program. The initial authorization of the fee program was extended numerous times until it was proposed to become a permanent part of the legislation. In December 2004, Congress passed the Federal Lands Recreation Enhancement Act (FREA) (P.L. 108-447), which permanently authorized the five federal land agencies to continue a recreation fee program for a period of ten years. The purpose behind FREA is to retain recreation fee revenues to supplement appropriations and other funding sources. Recreation fee dollars differ from appropriated funds from Congress in that $80 \%$ of the fee revenue stays on-site to support recreation programs. This incentive from the fee program assists local managers by utilizing the necessary funds needed to keep recreation sites open and maintained through quality standards. Visitors can also benefit from the recreation fee program through better quality of services, extended visitor center hours, and routine maintenance of trails etc.

The purpose of this study was to investigate the recreation fee program and respondents who recreate on the national forests of Washington, Oregon, and around the Denver metropolitan area of Colorado. More specifically, this study examined respondents' willingness to pay a maximum and appropriate fee as a predictor of viability for three types of recreational passes. The study also examined selected socio-demographic variables in willingness to pay. The three types of recreational passes that were examined within this study included the Northwest Forest Pass, Daily Pass, and the Golden Eagle Pass. Based on the findings from this study, a majority of respondents indicated a willingness to pay an appropriate fee according to the current fee prices currently being charged. 


\section{ACKNOWLEDGEMENTS}

First and foremost, I would especially like to acknowledge and thank my family and grandmother. My parents, Lee and Elizabeth; my sister, Katey; and my grandmother, Maggie (Bubba) has provided me with tremendous love, support, and encouragement throughout every step of my education career. Their support and belief in me have helped myself to overcome and pass through difficult times. I truly appreciate their words of encouragement and support along the way; I would be lost without you. I love you very much!

Most importantly, I would like to express my deep appreciation to my committee chair, Dr. Robert C. Burns, for his instrumental guidance, support, knowledge, and humor. I am very grateful he came to West Virginia University during my graduate studies and allowed me to complete my thesis under his guidance. I would also like to acknowledge and thank my other graduate committee members, Drs. Chad D. Pierskalla and David Smaldone for their help, wisdom, and dedication both in the classroom and through their service on my committee. I am very grateful for all they have given! Go eers! 


\section{TABLE OF CONTENTS}

page

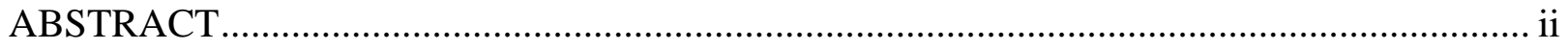

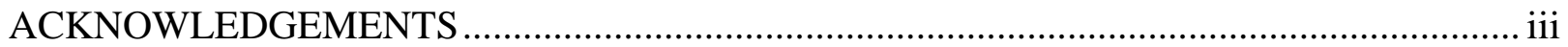

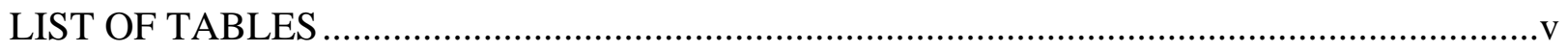

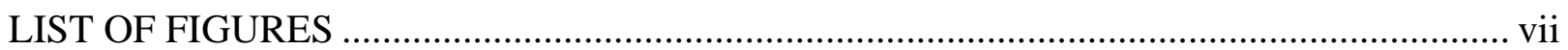

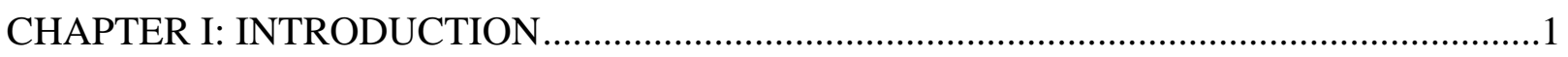

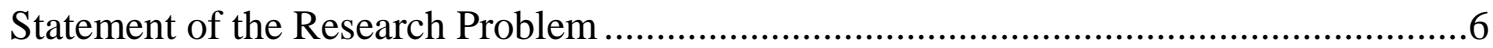

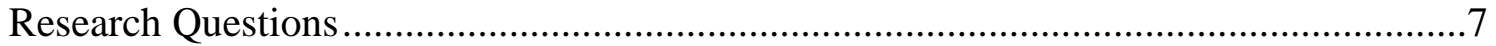

Limitations of the Study................................................................................... 7

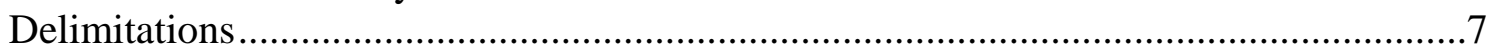

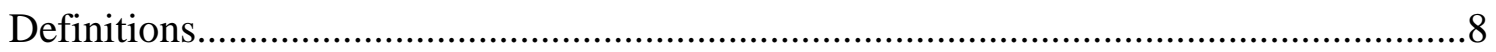

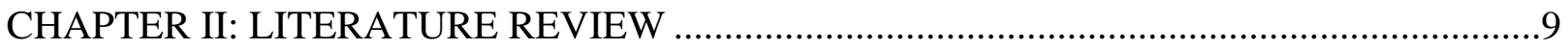

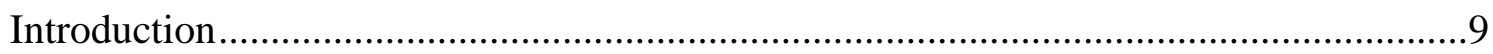

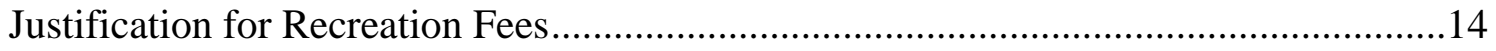

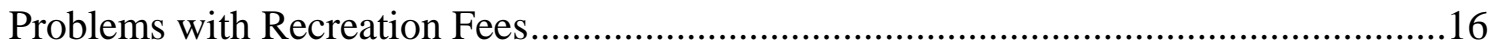

Willingness to Pay Issues of Recreation Fees......................................................18

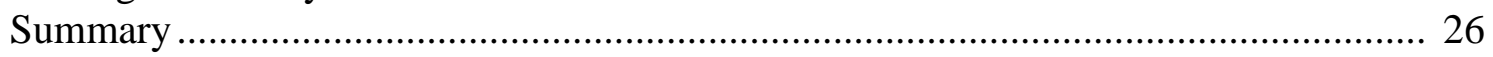

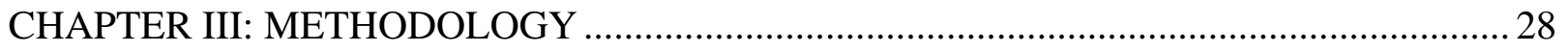

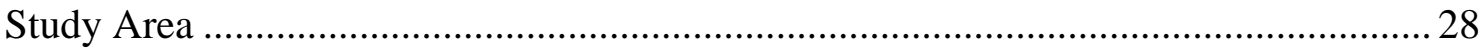

Data Collection ............................................................................................. 33

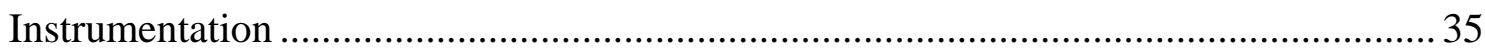

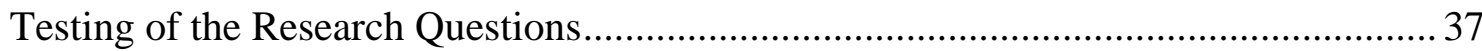

$\mathrm{R}_{1}$ : What is the socio-demographic makeup of the sample of respondents? ...... 37

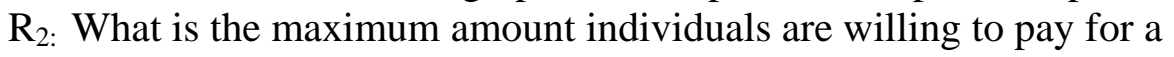
recreational pass? ............................................................................... 37

$\mathrm{R}_{3 \text { : }}$ What is the appropriate price individuals are willing to pay for a

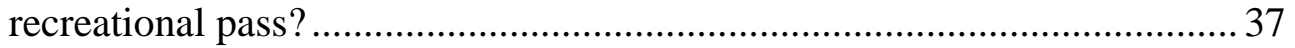

$\mathrm{R}_{4}$ : Do perceptions of the recreation fee program predict recreationists' maximum amount willing to pay for a recreational pass? .......................... 38

$\mathrm{R}_{5:}$ Do perceptions of the recreation fee program predict recreationists' appropriate price willing to pay for a recreational pass? ............................. 38

$\mathrm{R}_{6}$ : Are there differences in the willingness to pay model for various visitor segments based on gender, age, residence, education, and income? ............ 38 
$\mathrm{R}_{7}$ : What is the proper balance between fees and taxes? …………………….... 38

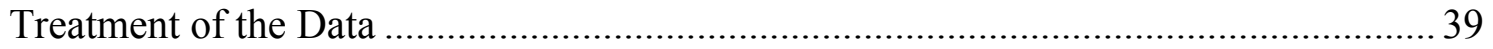

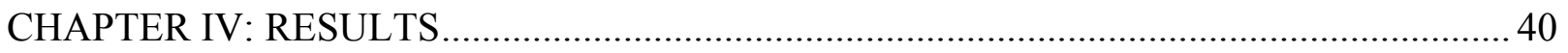

$\mathrm{R}_{1:}$ What is the socio-demographic makeup of the sample of respondents? ...... 40

$\mathrm{R}_{2}$ : What is the maximum amount individuals are willing to pay for a

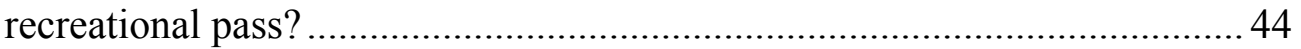

$\mathrm{R}_{3}$ : What is the appropriate price individuals are willing to pay for a recreational pass? ................................................................................... 47

$\mathrm{R}_{4}$ : Do perceptions of the recreation fee program predict recreationists' maximum amount willing to pay for a recreational pass? ............................50

$\mathrm{R}_{5:}$ Do perceptions of the recreation fee program predict recreationists' appropriate price willing to pay for a recreational pass? ...............................53

$\mathrm{R}_{6}$ : Are there differences in the willingness to pay model for various visitor segments based on gender, age, residence, education, and income? .............56

$\mathrm{R}_{7}$ : What is the proper balance between fees and taxes? .................................... 61

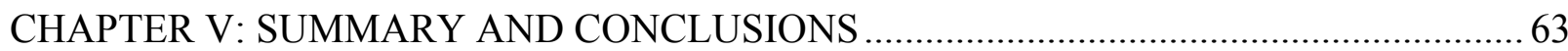

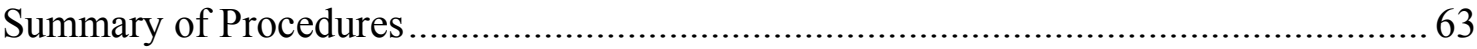

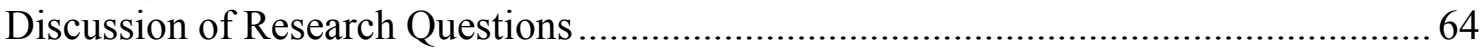

$\mathrm{R}_{1:}$ What is the socio-demographic makeup of the sample of respondents? .......64

$\mathrm{R}_{2}$ : What is the maximum amount individuals are willing to pay for a

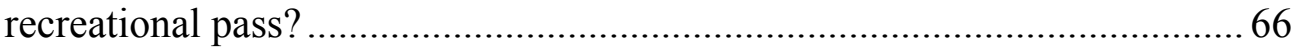

$\mathrm{R}_{3}$ : What is the appropriate price individuals are willing to pay for a recreational pass?

$\mathrm{R}_{4}$ : Do perceptions of the recreation fee program predict recreationists' maximum amount willing to pay for a recreational pass? ..............................69

$\mathrm{R}_{5}$ : Do perceptions of the recreation fee program predict recreationists' appropriate price willing to pay for a recreational pass? .............................. 71

$\mathrm{R}_{6}$ : Are there differences in the willingness to pay model for various visitor segments based on gender, age, residence, education, and income? ............ 72

$\mathrm{R}_{7}$ : What is the proper balance between fees and taxes? .................................... 74

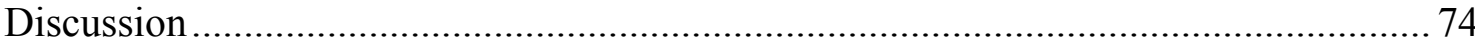

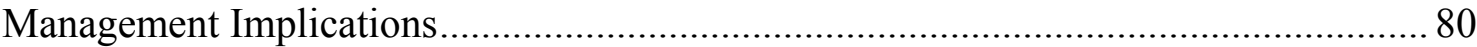

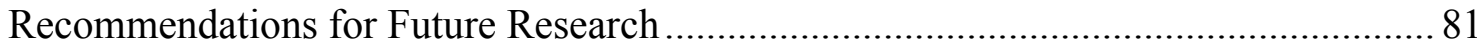

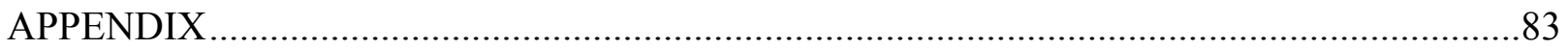

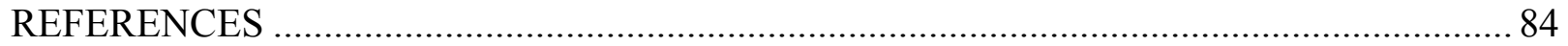

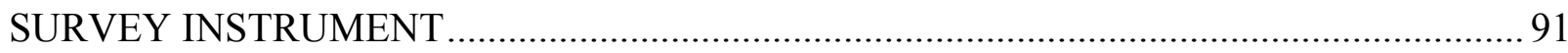




\section{LIST OF TABLES}

$\underline{\text { Table }}$

page

$1 \quad$ National Forests in Washington and Oregon ....................................................29

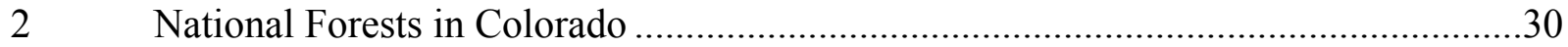

3 Socio-demographic Profile of Recreation Respondents .........................................42

$4 \quad$ Maximum Amount Willing to Pay for Northwest Forest Pass ..............................45

$5 \quad$ Maximum Amount Willing to Pay for Daily Pass .................................................46

6 Maximum Amount Willing to Pay for a Golden Eagle Pass ...................................47

$7 \quad$ Appropriate Price Willing to Pay for Northwest Forest Pass .................................48

$8 \quad$ Appropriate Price Willing to Pay for a Daily Pass ...............................................49

$9 \quad$ Appropriate Price Willing to Pay for a Golden Eagle Pass .....................................50

10 Multiple Regression Results for the Relationship Between Predictor Variables and Willingness to Pay the Maximum Amount for Northwest Forest Pass ......................51

11 Multiple Regression Results for the Relationship Between Predictor Variables and Willingness to Pay the Maximum Amount for Daily Pass

12 Multiple Regression Results for the Relationship Between Predictor Variables and Willingness to Pay the Maximum Amount for Golden Eagle Pass

13 Multiple Regression Results for the Relationship Between Predictor Variables and Willingness to Pay an Appropriate Price for Northwest Forest Pass. 
14 Multiple Regression Results for the Relationship Between Predictor Variables and Willingness to Pay an Appropriate Price for Daily Pass ...............................................55

15 Multiple Regression Results for the Relationship Between Predictor Variables and the Appropriate Willingness to Pay for a Golden Eagle Pass............................................55

16 Independent Samples t-test Results of Willingness to Pay by Gender ........................57

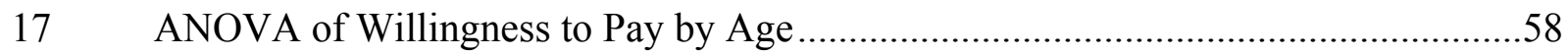

18 ANOVA of Willingness to Pay by Residence ........................................................5

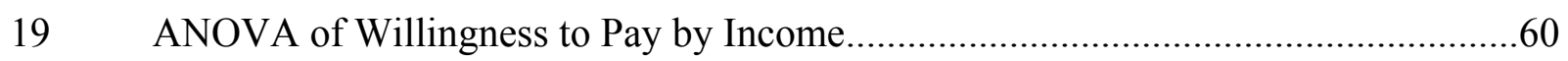

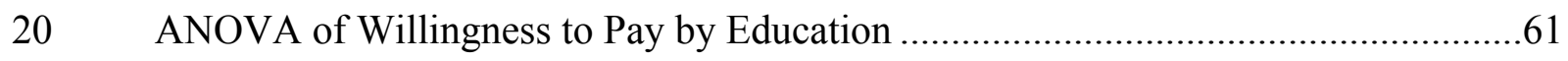

21 ANOVA of Willingness to Pay for an Annual Pass by Taxes and Fees......................62 


\section{LIST OF FIGURES}

$\underline{\text { Figure }}$

page

1 National Forests of Oregon and Washington..........................................................30

2 National Forests of Colorado 31 


\section{CHAPTER I}

\section{INTRODUCTION}

Over the past several years, research on recreation fees has increased substantially. The impetus for this research and corresponding thesis was the approval of a recreation fee demonstration program for selected public lands by the U.S. Congress in 1996. The recreation fee program enabled four land management agencies (U.S. Forest Service, National Park Service, Bureau of Land Management, and U.S. Fish and Wildlife Service) to charge fees to visitors as an alternative funding source. This potential funding source was perceived as an appropriate method of solving the problem of millions of dollars in maintenance and infrastructure backlog across these federal land agencies.

The idea of recreation fees to gain access for recreational use on public lands has been a topic of much debate. Within recent years, a number of studies have researched the topic of recreation fees on public lands from the conceptual, philosophical, and pedagogical perspectives (More, 1998). The idea of recreation fees has been a part of the National Park Service system for nearly a century, which predates the creation of the National Park Service (NPS) in 1916. The nation's first recreation fee was introduced at Mount Rainier National Park in 1908, followed by Crater Lake National Park in 1911, and Yosemite National Park in 1913 (Ostergren, Solop \& Hagen, 2005). The implementation of the recreation fee program resulted in an increase of research being conducted on the fee program and more specifically, on the willingness-to-pay for recreational opportunities on public lands.

In 1965, Congress established the Land and Water Conservation Fund Act (LWCF), which acknowledged the responsibility of visitors to contribute a portion of 
funding for recreation use. Congress subsequently implemented the recreation fee demonstration program in 1996. In 2004, Congress permanently established the recreation fee program through the Federal Lands Recreation Enhancement Act (FREA) (Public Law 108-447; 2004). The underlying principle behind the recreation fee program was not only to improve the maintenance backlog; but to also acknowledge that those who utilize specific services and facilities on public lands should pay a portion of their cost. The fee program has the potential to benefit taxpayers who never use these amenities by ensuring that those people who recreate at specific federal land areas assume a greater share of the cost. The permanent authorization of FREA provides the Department of Agriculture and the Department of Interior with the legal authority to continue the implementation of the recreation fee program. Another important point about the newly adopted recreation use act is that FREA limits fees to areas with specific kinds of infrastructure and services (U.S. Department of Interior, 2006).

Over the past few decades, most federal land management agencies have seen their recreation budgets shrink. With less money available it is difficult to maintain and improve recreation areas in a condition that meets customers' expectations. The proper management of public lands has therefore become more difficult as a result of decreasing appropriations from Congress. With appropriations being reduced, both legislatures and natural resource agencies have eagerly embraced alternative funding sources. Many recreation agencies have translated this into an emphasis on partnerships, recreation user fees, and a new way of doing business (More, 2002).

Some fee proponents justify the recreation fee program as being an important implementation for the future of economic self-sufficiency (McCarville, 1995). Still 
others agree that funding public lands through recreation fees can be economically more efficient than funding through taxes (Fretwell, 1999). Resource managers under the traditional funding program had the tendency to be more loyal and responsible to Congress. The recreation fee program encourages managers to become more responsive to visitors and more protective of their natural resources. Recreation fees have also been suggested as a management tool for public lands to overcome the problems recreation areas are facing (Nyaupane, 2004). Over the past several years, many public land areas have experienced a high level of recreation use. A high impact recreation area can have many detrimental problems, such as overcrowding, increased pollution, degradation of natural resources, congestion and poor quality of visitor facilities (Nyaupane, 2004).

Research on recreation fees has covered an extensive range of topics. The range of topics has included public response toward fees, impacts of fees on visitors, methods of determining fees, and philosophical aspects of recreation fees. Many recreationists generally indicate support for the recreation fee program; but recreationists agree that a combination of taxes and user fees should be used to maintain the quality of recreation services on public lands (Bowker, Cordell \& Johnson, 1999; More \& Stevens, 2000).

The acceptance of recreation fees can depend on the amount of fees charged and the willingness to pay by a visitor. With the implementation of the recreation fee program, resource managers and researchers have faced this challenge in determining appropriate fees for recreation areas (Richer \& Christensen, 1999). This thesis can assist resource managers with a better understanding of the price level respondents were willing to pay for their recreational experience. 
The pricing of services is done quite differently in the public sector than in the private sector. In the private sector, the main objective for a business is to maximize profit by establishing the highest price possible. A business within the private sector typically sets their price of products or services based on their investment and expected profit. The public sector typically seeks a different objective than many agencies or corporations in the private sector. For public land agencies, the main objective is not maximizing profit. The objective is to support the overall cost of the agency without decreasing the number of visitors to public land areas (Kyle, Graefe \& Absher, 2002; Nyaupane, 2004).

Previous literature on willingness to pay (WTP) studies has followed the contingent valuation method (CVM). This method was utilized as a way to estimate the monetary value of goods and services not traded in typical markets (Ajzen \& Driver, 1992; Mitchell \& Carson, 1989). However, WTP focuses on an individual's ability to pay fees and ignores the social responsibility of equity and fairness (Richer \& Christensen, 1999). Recently, the concept of appropriate price has been suggested by some researchers (Kyle et al., 2002; Richer \& Christensen, 1999). An appropriate price (AP) elicits a balance between fee revenues and the publics concern for fairness, equity and others' ability to pay. According to much of the recreation fee literature, the public's concern is focused more around the fairness of recreation fees (Bengston \& Fan, 2001; McCarville, Reiling \& White, 1996; Williams, Vogt \& Vitterso, 1999). McCarville (1996) proposed that fair price seems more important than WTP because fair price tends to consider more social aspects than WTP. McCarville suggested that the assessment of pricing is influenced by past experiences with fees, proximity, and familiarity of the area. 
Several variables have the potential to impact respondents' WTP and AP levels. Some of these variables include past payment history (McCarville, 1996) place attachment (Fleisher Trainer \& Norgaard, 1999; Kyle et al., 2002; Williams \& Watson, 1998), history of use for the recreation setting (Williams et al., 1999), information (Kim \& Crompton, 2001; McCarville et al., 1996;), and income (More \& Stevens, 2000).

More (2002) stated that for resource based recreation, low-income individuals are already priced out by the high equipment and travel costs. This concept has been theoretically argued as well. Kyle et al., (2002) demonstrated that income also impacted WTP and AP responses. Williams et al. (1999) found that income levels were associated with fee support. For example, as income increased, so did respondent's level of support for the recreation fee program.

Bowker et al. (1999) researched various socio-demographic variables including education, gender, race, household size, income, and geographic variables. The results from this research concluded that less educated, older, Black and Hispanic, and poor individuals were less supportive of user fees than more educated, younger, White and wealthy Americans (Burns \& Graefe, in press; Nyaupane, 2004). 


\section{Statement of the Research Problem}

The primary purpose of this research study was to investigate the recreation fee program and respondents' willingness to pay as a predictor of viability for three types of recreation passes. Given the task of generating revenue and maintaining public access, research on recreationists' willingness to pay can be an important source of knowledge for managers. This study can assist resource managers and public policy personnel to address willingness to pay issues and to understand respondent preferences for an appropriate price. First, this thesis will explore the willingness to pay of respondents who have recreated in the past 12 months on a national forest within the states of Washington, Oregon, or around the Denver metropolitan area of Colorado. Second, this thesis will determine if various socio-demographic variables and perceptions of the recreation fee program will predict respondents' willingness to pay the maximum and appropriate amount for three different recreational passes.

Previous studies on the recreation fee program were typically conducted on-site and at the micro-level, which has a tendency to ignore the opinions of the general public (Bowker et al., 1999). On-site studies typically exclude non-users and individuals who have been displaced to non-fees areas due to personal opinions or beliefs about the recreation fee program. The sampling method conducted within this study overcomes this problem by focusing on the general population, which will allow the findings to be a better representation of the overall population (Nyaupane, 2004). 


\section{Research Questions}

The following specific questions are proposed:

$\mathrm{R}_{1:}$ What is the socio-demographic makeup of the sample of respondents?

$\mathrm{R}_{2:}$ What is the maximum amount individuals are willing to pay for a recreational pass?

$\mathrm{R}_{3}$ : What is the appropriate price individuals are willing to pay for a recreational pass?

$\mathrm{R}_{4}$ : Do perceptions of the recreation fee program predict recreationists' maximum amount willing to pay for a recreational pass?

$\mathrm{R}_{5 \text { : }}$ Do perceptions of the recreation fee program predict recreationists' appropriate price willing to pay for a recreational pass?

$\mathrm{R}_{6}$ : Are there differences in the willingness to pay model for various visitor segments based on gender, age, residence, education, and income?

$\mathrm{R}_{7}$ : What is the proper balance between fees and taxes?

\section{Limitations}

This study was derived from a secondary analysis of data. Interviewers from University of Florida's Survey Research Center initially conducted the survey interviews. Although all the interviewers were trained, there is a possibility of having potential differences among the interviewers. The results of this study only focused on the national forests within the states of Washington, Oregon, and around the Denver metropolitan area of Colorado, which may not be generalizable to the general population of recreationists in the United States.

\section{Delimitations}

This study was delimited to residents who have a working telephone within their household and are 18 years of age or older in the states of Washington, Oregon, and the Denver metropolitan area of Colorado. 


\section{Definitions}

The following definitions are given for the purpose of this study:

Appropriate Price is a balance between fee revenues and the public concerns of equity, fairness, and others' ability to pay.

Federal Lands Recreation Enhancement Act permanently establishes the recreation fee program in order to help provide a stable source of revenue for the five federal land management agencies.

National Forests refer to lands and waters managed specifically by the USDA Forest Service, which is different than National Parks, state parks, or other recreation areas.

Outdoor Recreation refers to water, land, or snow-based activities.

Recreation Fee Program is a program designed to provide public lands with an increase of revenue in order to deal with the backlog of maintenance on public lands, thereby helping to improve the quality of visitor services and enhancing the protection and maintenance of recreational resources (Bengston \& Fan, 2001; Schneider \& Budruk, 1999).

Recreationist refers to a Forest Service survey respondent who answered 'yes' to the question, "Have you participated in any outdoor recreation activities during the past 12 months?"

Willingness to pay is examined as the maximum amount respondents are willing to pay for their recreational experience. It can be conceptualized as the intention to pay a certain amount of money for engaging in a leisure activity (Ajzen \& Driver, 1992). 


\section{CHAPTER II}

\section{REVIEW OF LITERATURE}

The purpose of this chapter is to review the relevant literature related to the recreation fee program and more specifically, review willingness to pay issues of recreation fees followed by the publics' responsiveness to the recreation fee program, and the equity and fairness towards recreation fees.

\section{Introduction}

Over the past few years, many concerns have been expressed about the future costs of maintaining and operating recreation sites within the federal land management agencies (Bengston \& Fan, 2001). Many of these concerns have been focused around the deteriorating infrastructures and the decline in visitor service qualities. These concerns led Congress to seek additional funding sources other than appropriated funds, which resulted in the implementation of the recreation fee demonstration program. The purpose behind the fee program is to provide public lands with an increase of revenue in order to deal with the backlog of maintenance on public lands, thereby helping to improve the quality of visitor services and enhancing the protection and maintenance of recreational resources (Bengston \& Fan, 2001; Bowker et al., 1999; Williams, Vogt, \& Vitterso, 1999).

With budgets being reduced, both agencies and legislatures have eagerly embraced alternative funding sources; and within recreation agencies this has translated into an emphasis on partnerships, user fees, and a new way of doing business (More, 2002). This led Congress to first authorize the recreation fee demonstration program through the Omnibus Consolidated Appropriations of 1996, which was initially authorized as a three-year pilot program. This initial authorization of the program was 
extended numerous times and was proposed in December 2004 to become a permanent part of legislation when President George W. Bush authorized the Federal Lands Recreation Enhancement Act (FREA), H.R. 3283 (USGAO, 2004). The recent authorization of this act for recreation fees could potentially have a significant impact on the future of public land recreation management policy. The act proposes to permanently establish the recreation fee program to help provide a stable source of revenue for the five federal land management agencies. With the exception of the Bureau of Reclamation, all of these agencies had fee authority under the initial recreation fee program and the Land and Water Conservation Fund Act of 1965. The purpose behind FREA is to retain recreation fee revenues to supplement appropriations and other funding sources in order to improve, repair, operate, and maintain recreation sites to quality standards (Benzar, 2005; Rey, 2005).

According to the Forest Service's interim implementation guide, the Forest Service assumes that appropriations received for recreation in the future will not be sufficient to meet recreation infrastructure and service needs. While the revenue received from recreation fees will be helpful, it is only part of a more comprehensive funding strategy. According to Mark Rey, Under Secretary for the United States Department of Agriculture, fees collected under FREA are one part of a comprehensive recreation business model. This model identifies revenue and other resources based on congressionally appropriated funds, volunteer assistance, interagency cooperation, partnerships with the private sector, commercial operations and funds leveraged from other resources. 
The recreation fee program was initially legislated through Congress to find alternative methods for funding resources within the four federal land management agencies, which included the Forest Service (FS), National Park Service (NPS), Fish and Wildlife Service (FWS), and the Bureau of Land Management (BLM) (Bates, 1999; Fretwell, 1999). Together each of these federal agencies manage about 632.7 million acres of land. Of this, the BLM manages 270 million acres, the USFS manages 191 million acres, the FWS manages 91 million acres, and the NPS manages the remaining 80.7 million acres (Taylor, 2000).

The authorization of the fee program legislation in 1996 provided a major step forward toward decentralizing the command and decisions made from Congress to the specific land management agencies. The recreation fee program authorized more control to local managers within these agencies to charge fees to visitors, which was designed to help retain additional revenues for use in addition to other appropriate funds from Congress (USGAO, 2003).

Recreation fees that are charged to visitors can be generally categorized into two different areas: as an entrance fee or a user fee. An entrance fee is categorized as a general charge to the visitor for short-term access to one of the land management agency's recreation sites. Most of these entrance fees are charged to visitors who are seeking access to key features within a recreation area. For example, visitors pay $\$ 10$ per car to enter Zion National Park in Utah. Most of these entrance fee charges occur on a per-vehicle basis however, some charges do occur for a particular visitor who might seek to hike or bicycle in a particular recreation area. The recreation user fee is typically charged in return for a service provided to the visitor such as camping, backcountry 
hiking, boat launching, or participating in an interpretive tour of a recreation site. For example, visitors can pay $\$ 5$ per day for the opportunity to hike or backpack in Paria Canyon, which is a BLM recreation fee site in Utah (USGAO, 2003).

An initial tenet of the recreation fee program was to allow each federal land management agency the ability to choose between 10 and 100 sites to test the overall validity of the program (Fretwell, 1999). However, beginning in the fiscal year 2002, Congress mandated the limit (100) of fee demonstration sites be lifted, which has resulted in the present number of fee demonstration sites (USGAO, 2004). As of September 30, 2003 the numbers of the fee program sites used by each federal agency were as follows: NPS - 236, BLM-187, FWS-109, and FS - 105. In the fiscal year 2003, the total revenue generated from the fee demonstration program resulted in about $\$ 177$ million. The breakdown of the total revenue generated from each agency includes, NPS $-\$ 123.5$ million, BLM $— \$ 10.3$ million, FWS $— \$ 3.8$ million, and FS— $\$ 38.8$ million. In addition, the total FY 2003 obligations for spending revenue included 53 percent spent towards maintenance projects; 12 percent for projects to improve visitor services; and 11 percent for resource protection (USGAO, 2004). As an example, a fee demonstration site within the Forest Service could be a group of forests, such as the National Forests in the state of Utah. Alternative fee demonstration sites might consist of an individual forest or even a specific area or a particularly activity within a forest, such as Mirror Lake in the Wasatch-Cache National Forest in Utah (Nyaupane, 2004).

Previous to the passing of the recreation fee legislation, all sites collecting an entrance or user fee were required to deposit those funds into a special United States treasury account. These funds were to be used for specific purposes such as facilities 
maintenance and resource protection. The funds within this account only became available to land management agencies through congressional appropriations (USGAO, 2004). An incentive to the recreation fee program legislation allowed each federal agency to keep at least $80 \%$ of the fees collected at each site, with the other $20 \%$ being used on an agency wide basis. Plus, the Department of Interior (DOI) and US Department of Agriculture (USDA) managers have the power and authority to establish their specific spending priorities with some guidance provided by their specific corresponding agency headquarters (USGAO, 2003). As a result, the total revenues collected at each site have the potential to yield a substantial improvement and quality in the sites facilities. For example, the Forest Service advises their resource managers throughout the country to appropriately spend fee demonstration revenues on the needs expressed by their recreation visitors. In terms of visitors' preferences, the Forest Service will likely assume that visitors will be more accepting of paying a fee if they can conceptualize and even visualize that their money is actually being spent on improving recreational visitor services at that site. In addition, the recreation fee legislation gives more of an incentive or guidance to maintain existing facilities such as restrooms and cabins, as opposed to building new infrastructures (USGAO, 2003). In 2002, the USDA and DOI formed the Interagency Recreational Fee Council (Fee Council) to help facilitate coordination and consistency among the agencies on recreation fee policies. This council is helping to ensure increased public support for the fee program by minimizing confusion so recreation fees are more convenient and beneficial (USGAO, 2003). 


\section{Justification for Recreation Fees}

Over recent years, many public land managers have seen more challenges in managing recreation and natural resource areas with the decreasing amount of appropriations from Congress. Through this traditional process, land managers had a small amount of control over expenditures at their land management sites. If managers carefully conserved some of these funds, they were still required to return this amount to the national treasury office. Most managers were being penalized for these conservative actions by having their budget cut the following year (Nyaupane, 2004). For example, if a specific site generated revenue under the traditional program, it did not mean anything to that particular site because the revenue would be returned to the national treasury office (Fretwell, 1999). The recreation fee program can therefore, provide some incentives for managers to become more responsible for their specific management site. It has been surmised that under the traditional program, managers had a tendency to be more responsible and loyal to Congress than to visitors at their site. The implementation of the recreation fee program has the potential to lead managers to become more responsive to their visitors, more protective of natural resources, and more responsible with their maintenance issues.

Some fee proponents justify that the recreation fee program is important for the future of economic self-sufficiency. These proponents feel the implementation of recreation fees on public land management areas will be seen by some as a necessary part of the future (McCarville, 1995). This realization might become part of the future because many of our public lands are seeking assistance from other funding sources to get them out of trouble. It should also be noted that Americans are visiting our national 
forests, parks, wilderness, and recreation areas in record numbers. With the growing popularity in these outdoor recreation sectors, many of our public land areas are approaching or even exceeding their recreation carrying capacity. This may lead to detrimental problems such as overcrowding, degradation of natural resources, increase in pollution, congestion and poor quality of visitor facilities and services (More, 2002). The United States General Accounting Office's (1998) report to Congress outlined four major concerns about our public recreation lands, which included:

- multibillion dollar backlog of maintenance and infrastructure

- poor quality of visitor services

- deterioration of many natural and cultural resources and

- financial resources available in federal appropriations are not significantly sufficient to curb the growing deterioration of resources, services, and recreational opportunities managed by each federal agency.

The implementation of the recreation fee program can potentially help to reduce the multibillion-dollar backlog that has accumulated over the years and limit the amount of overcrowding and congestion.

Since the inception of the recreation fee program, the four land management agencies (NPS, USFS, FWS, and BLM) have collected over $\$ 1$ billion from recreation fees. In addition, budget requests from the Department of Interior and the Department of Agriculture indicated that the agencies would expect to collect \$138 million and $\$ 46$ million respectively from the fee demonstration program in fiscal year 2005 (USGAO, 2004). 


\section{Problems with Recreation Fees}

Within recent years, managing public land recreation and natural resource areas has become more of a challenge. This challenge resulted from the decreasing amount of appropriation funds from Congress to public land areas. Many opponents of the recreation fee program argued that it is unfair and discriminates against lower-income users, senior citizens, minority groups, and other people with disabilities. Some of these groups have become displaced or even reduced their amount of recreation within these areas (More, 2000; Schneider \& Budruk, 1999). For example, visits to recreational areas generally require some kind of financial commitment that lower income visitors may not be able to afford, including travel costs (e.g. high fuel prices) and many recreational activities require expensive gear such as sleeping bags, tents, cookware and so forth (More, 1999; Reiling \& Anderson, 1985). More \& Stevens (2000) indicated that 23\% of low-income respondents had either reduced their participation in resource based recreation or were displaced from the area because of recreation fees, compared to only $11 \%$ of high-income respondents. More $\&$ Stevens (2000) also found that a $\$ 5$ daily fee to access public lands would affect almost half of the low-income people compared to $33 \%$ of high-income people. The question is then, what is the purpose of public lands? Is it to no longer to serve the public or just the selected few who have the financial means to do so? "The very existence of the fee program violates the fundamental values about the right to free access to public lands, which has the possibility to destroy the overall experience that some individuals seek" (Bengston \& Fan, 2001, p. 16).

Watson and Herath (1999) suggested that with the implementation of the fee program there exists the chance of changing the relationship between visitor and agency 
to buyer and seller. If people are perceived as customers when visiting a public land area, then it is fair for the customer to ask in return, what they are getting for their money (More, Dustin, \& Knopf, 1996). Public lands have the potential to lose the visitor and agency relationship, and even the individuals who volunteer their time. Watson and Herath (1999) provided an interpretive scenario of a situation that may exist in a major U.S. retail chain to explain this situation.

Would you be willing to voluntarily sweep floors at Wal-mart? The answer to this question is probably no, because Wal-mart is a company that employs the full price mechanisms, which is a lot different from our public lands. Who volunteers at Wal-mart? No one volunteers at Wal-mart because it is a commercial business, which is expected to pass the costs of providing a service to each customer. (p.328)

Many of our public land areas however, may benefit from individuals who are willing to volunteer their time in these areas. Charging user fees has the potential to affect the loyalty of the public to these areas (Nyaupane, 2004; Watson \& Herath, 1999). Also, recreation fees may change the view of public land areas to a more utilitarian or anthropocentric view.

Some opponents also argue the fee program provides the public with a form of double taxation, since their taxes are already paying to sustain and support the operation of public lands. This argument suggests that the recreation fee program has the potential to displace visitors to non-fee sites. In a recent example, data were collected from a nonfee National Forest beach area. A majority of the respondents chose that particular site because it was free, and one-third of respondents indicated their visit was altered as a 
result of the fee program (Schneider \& Budruk, 1999). In addition, those individuals concerned about maintaining access to public lands for everyone, regardless of their income status, may consider recreation fees unfair (e.g., lower income visitors do not pay a lower fee). Within our society the concern for the economically disadvantaged can be readily observed through a number of services, including housing subsidies, food stamps, Medicare programs, and the like. It is not surprising then that support exists for maintaining access to public recreational lands regardless of income levels (Kyle, Graefe \& Absher, 2002, p. 73).

In the late 1950s, legislation was enacted to collect fees through the Independent Office Appropriations Act. During this time, many federal agencies did not rely on fees as a major source of funding because the outdoor recreation philosophy during this time thought these areas should be open to all socioeconomic classes at no cost (Warren \& Rea, 1998).

\section{Willingness to Pay Issues of Recreation Fees}

The research conducted on recreation fees and the pricing of recreation activities on public lands dates to the 1960 s, with some occasional findings on this topic in earlier literature (Bowker et al., 1999; Warren \& Rea, 1998). The idea of recreation fees has been a part of the national park service system, which predates the 1916 creation of the National Park Service (NPS). Areas such as Mount Rainier National Park initiated the actual concept of a recreational user fee in 1908, followed by Crater Lake National Park in 1911, and Yosemite National Park in 1913 (Ostergren et al., 2005). Fees were charged during this time within the parks mainly to offset the construction of road building costs (Stone, 1996). The authorization of the recreation fee demonstration program in 1996 
resulted in a great deal of research being conducted on the fee program and more specifically, on willingness-to-pay for recreational opportunities within public land areas.

Before 1996, many public land managers had limited experience with implementing fees. Accordingly, land managers had difficulty in choosing an appropriate price for their land management sites. The implementation of the recreation fee program and charging an entrance fee for use of public lands became a very controversial issue; and many managers became concerned about the public acceptance of these fees (Crompton, 1981; McCarville, 1995). Much debate has surrounded the issue of whether to charge or not charge fees for access to public lands. This issue has transcended across economics, ethics, equity, and management (Ostergren et al., 2005). For example, the rationale of fairness with recreation fees relates to the notion that charging fees for access to public lands is unfair to the public (Bengston \& Fan, 2001; McCarville et al., 1996; More \& Stevens, 2000; Williams et al., 1999). Fairness relates to an individual's perception of what is right for a particular setting. If a recreationist sees a benefit from the fees they paid for access to a public land area, they would perceive it as fair. Kamen and Toman (1970) suggested that participants may develop a fair price level and, if actual prices deviate from this level, consumers may seek alternative price levels that are more consistent with their expectations. Plus, fairness is also associated with the actual value recreationists' receive from their investment (McCarville et al., 1996). Some individuals have also argued that fees are unfair because they have already paid taxes to cover the costs of public services. McCarville et al. (1996) noted that prices that appear to be fair receive minimal public resistance or comment, however, unfair prices can generate considerable amount of hostility or even displacement from the public sector. 
Dustin, More, and McAvoy (2000) made the argument that our public lands, specifically National Parks, should be fully funded through taxes to maintain the democratic nature of what they called, "the best idea we ever had." Some other proponents have made a compelling argument that those who utilize the recreational resources should pay for those services. Although a few authors have suggested that recreation fees can displace and cause too much of a financial burden on lower income groups (More \& Stevens, 2000; Reiling, Cheng, \& Trott, 1992; Schneider \& Budruk, 1999), other authors argue that the poor may already be priced out of the market because of other economic constraints such as travel costs (Reiling \& Anderson, 1985).

However, other research suggests that recreation fees do not overly burden recreationists (Ostergren et al., 2005; Williams, Vogt \& Vitterso, 1999). Regardless of the numerous debates about recreation fees within our public lands, most researchers agree that there is a general acceptance of recreation fees. However, the consensus seems to agree that a combination of taxes and fees is necessary to provide adequate recreation facilities and services on public lands (Bowker et al., 1999; More \& Stevens, 2000). The task for researchers and public land managers is to determine the proper balance between taxes and fees.

Richer and Christensen (1999) suggested that the overall acceptance of fees depends on how much fees actually cost the visitor. From this it is possible to suggest how much to charge recreation visitors' for use of our public lands, although it is a challenging task for land managers and even researchers. A few studies from the fee literature suggest that access to public land can be price-elastic (Kyle et al., 2002; Richer \& Christensen, 1999). In general terms, this means that as the price of fees increase, the 
number of recreation visitors' decrease. Kyle et al. (2002) suggested that the overall objective of our public lands should not only focus on utility maximization, but also on increasing the maximum number of people to these areas. Public land managers and researchers therefore need to develop an appropriate fee for their recreational area that balances both revenue and visitation.

Rosenthal, Loomis \& Peterson (1984) proposed an economically efficient pricing strategy for publicly provided outdoor recreation areas by using concepts from microeconomic theory. This theory proposed a pricing strategy to the outdoor recreation field that was based on maintaining the actual costs of providing the recreation services, but did not include the willingness to pay. If the overall marginal cost of recreation activity use is zero or it is way too expensive to administer fees, charging fees in the future will not be worth it (Rosenthal et al., 1984). Marginal costs include the actual cost of increasing visitor use capacity in terms of overcrowding, congestion, more impacted areas, and operating expenses. These authors opined that during peak periods when congestion will be the highest, (e.g., weekends and holidays), a higher fee price might be recommended, which can help cover the marginal costs. However, this model tended to disregard the effect of price on certain segments of the population (Nyaupane, 2004).

The contingent valuation method (CVM) and specifically, willingness to pay (WTP) concept, has been another method developed through research in valuing nonmarket goods. A review of the recreation fee literature shows that many willingness to pay studies have followed the contingent valuation method (Ajzen \& Driver, 1992; Loomis \& Walsh, 1997). According to Ajzen and Driver (1992): 
The CVM has become a tool for placing dollar amounts or values on goods and services that are typically not exchanged in the marketplace. Typically, economists use observed market choices, such as a decision to buy or not buy a particular product at a posted price, to determine value. For example, no competitive market mechanisms exist that would assign monetary values for opportunities to hike in a wilderness area or bicycle in an urban park. Therefore, the WTP method can be conceptualized as an intention to pay a certain amount of money for engaging in a leisure activity. (p. 298)

This method usually results in respondents being asked the maximum amount they are willing to pay for a non-market good such as improving the quality of a camping area. However, when a respondent indicates his/her WTP for a non-market good, it also follows or presumes that this respondent would be willing to pay any price below the amount stated (Kyle et al., 2002).

Ajzen and Driver (1992) used an extension of the theory of reasoned action (TRA), the theory of planned behavior (TPB), to explain the WTP for a user fee for engaging in five leisure activities. The central element in the TPB is understanding the individual's intention to perform a given behavior. This theory assumes three predictors, including attitude toward the behavior, a social component termed subjective norm, and the degree of perceived behavioral control. The attitude toward the behavior refers to the degree that the individual has a favorable or unfavorable evaluation of the behavior (e.g., attitude toward the recreation fee program). The concept of subjective norms refers to social pressure to either perform the behavior or not. Lastly, perceived behavioral control implies the perceived ease or difficulty of performing the behavior, which is also 
assumed to reflect past experiences as well as obstacles (Ajzen \& Driver, 1992). With the theory of planned behavior, the more favorable the attitude, subjective norm, and the greater perceived behavioral control, the more likely the behavior will be performed by the individual (e.g., WTP a recreation fee).

Many WTP studies within the literature have followed the CVM. This method was developed as a tool to estimate the monetary value of goods and services not traded in typical markets. But this method was not designed to help managers in making their pricing decisions; plus, it falls short in explicitly providing an appropriate price to charge for a recreation experience (Kyle et al., 2002; Richer \& Christensen, 1999).

An important variable with the fee program is establishing an appropriate price (AP) for recreation visitors. Richer and Christensen (1999) initially introduced the concept of appropriate price (AP) in order to balance fee revenues and the public's concerns of fairness, equity, and other users' ability to pay. An appropriate price offers a balance between the need for revenues and the overall desire to maintain access to all visitors. The authors posited that public land access is a fundamental right that should be afforded to everyone regardless of an individual's economic means. The results from their study suggested that a majority of users considered willingness to pay (refers to maximum amount) greater than the appropriate price for a fee. In addition, the study concluded that appropriate fees for public land recreation should take into consideration the views of non-visitors as well. The research findings of Kyle et al. (2002) are consistent with Richer and Christensen (1999) in suggesting that appropriate price may be a lesser value than the monetary value associated with a respondent's willingness to pay. Kyle et al. (2002) also examined some normative issues that could potentially 
influence WTP or AP levels. These included fairness, level of income, payment history, equity, discrimination, management application, place identity, and place dependence. Among the afore-mentioned, fairness, discrimination, management application, and use history were significantly correlated with WTP and AP. However, only past payment history was significantly correlated with WTP and not AP. This significant correlation suggests that AP can be more appropriate for a newer recreation site since it may not be influenced by past payment history (Kyle et al., 2002).

The recreation fee literature related to willingness to pay demonstrates that several variables have the potential to affect recreationists' attitudes toward the fee program and their corresponding willingness to pay (WTP) and appropriate price (AP) estimates. These different variables include history of paying fees, income, place attachment to the recreation setting, and their use history of that recreation setting (Kyle et al., 2002).

McCarville (1996), suggested that several theoretical perspectives of past payment experience are likely to influence an individual's price expectations. The theories include adaptation theory (Helson, 1964) and the prospect theory (Kahneman \& Tversky, 1979), which suggests that individuals are specifically guided by price points that are held within their memory. According to McCarville, the price last paid provides a price anchor that individuals can use when determining their personal price expectations. The author goes onto suggest that previous experience or personal preference may influence the importance of price last paid in their development of price expectations. The adaptation theory also presumes that as an individual encounters repeated exposure to a fee, it can eventually encourage the acceptance of the fee program (Reiling et al., 
1985). Fees that have been traditionally charged over many years tend to receive more support than a newly implemented fee. This idea may also be related to the reference price (also known as status quo), which relates to what individual's expect to pay. McCarville and Crompton (1987) made a distinction between WTP (a measure of consumer demand) and reference price (what consumers expect to pay) with the latter strongly influenced by the price last paid and by past payment history (Kyle et al., 2002; McCarville, 1996). Many recreationists oppose the implementation of the fee program because these new fees infringe on their price expectations for a recreational service that has been traditionally free. In general, the public is more accepting of fees when they have previously paid fees for recreational opportunities in the past (McCarville, 1991; McCarville, 1996).

Socio-demographic characteristics such as age, education and more importantly income have also been found to be correlated with opinions regarding pricing (McCarville, 1995; McCarville, Reiling \& White, 1996; More \& Stevens, 2000; More 2002). McCarville (1995) suggested the classic rationalist perspective, in that prices will limit access based upon participants' ability or willingness to trade fees for services (McClosky, 1982). This burden would weigh most heavily on members within our society who possess the fewest resources, and such fees can be looked upon to be discriminatory in their application. Many researchers have suggested that implementing recreation fees within our public lands can lead to discriminatory impacts on low-income users and individuals at the income margin. McCarville (1995) states that repeated exclusion based on the inability to pay may create profound perceptions of discrimination, marginalization, and unethical treatment. For example Reiling et al. 
(1992) focused their research on a state park within Maine and recreational camping fees. The study found that compared to high-income campers, low-income campers relocated to areas that offered no fees as the fees rose. Another study within US Army Corp of Engineers day use areas revealed that compared to high-income users, low-income users were more sensitive to higher fees and were likely to become more displaced (Reiling, McCarville, \& White, 1994). In addition, More and Stevens (2000) found a significant exclusionary impact within their study, which showed low-income respondents became more responsive to access fees, and were more likely to alter their behavior because of fees.

More (2002) suggested that many low-income people are already priced out of participating in resource-based recreation by the high travel and equipment costs. Kyle et al. (2002) demonstrated that income also impacts WTP and AP responses. Williams et al. (1999) also found that income level was associated with support for fee programs. For example, as income rose, so did respondent's support for the recreation fee program. In addition, Bamford, Manning, Focier, and Koenemann (1988) and Reiling, McCarville, and White (1994) found that low-income users reported lower WTP estimates. Bowker et al. (1999) researched various sociodemographic variables, including gender, education, household size, race, income, and geographic variables. The results of this research suggested that older, less educated, Black and Hispanic, and poor individuals were less supportive of user fees than younger, more educated, Whites and wealthy Americans (Burns \& Graefe, in press; Nyaupane, 2004). 


\section{Summary}

The permanent implementation of the recreation fee program for the next ten years represents a major shift in the management of our public lands. Many philosophical issues surround the recreation fee program pertaining to its fairness and justice. The issue of charging recreation user fees and the willingness to pay for use of federally managed public land is neither simple nor straightforward. The fee program has been contentious over the years, which has engendered strong support and equally strong opposition. However, since the fee program will remain in place for the next ten years, it is important for public land managers and researchers to understand the viability of the fee program and visitors' willingness to pay for their recreational experience. 


\section{CHAPTER III}

\section{METHODOLOGY}

The following chapter describes the research methods used within this study. The research for this study was based on a larger study initially conducted by the University of Florida and The Pennsylvania State University for the Pacific Northwest region of the U.S. Forest Service. Secondary data analysis was used in this study from data that was previously collected through telephone recreation use surveys. The data was collected through a random telephone survey of residents within three western states, including Washington, Oregon, and the Denver, Colorado metropolitan area during the time period of December 2003 through February 2004. This study was conducted to reveal respondents' attitudes and opinions toward the recreation fee demonstration program. Most research studies on recreation fees were previously collected on-site, which typically excludes individuals who have been displaced to other non-fee areas. Accordingly, an on-site recreation survey may not be a true representation of the general recreating public (Bowker et al., 1999; Nyaupane, 2004). To overcome this dilemma, the population sample for this study was comprised of all adult residents (18 years or older) with a working telephone.

\section{Study Area}

The respondents within this study were asked questions pertaining to their recreation use on a national forest within the states of Oregon, Washington or around the Denver, Colorado metropolitan area within the past 12 months. The Pacific Northwest Region of the USDA Forest Service, which is also known as Region 6, includes 19 National Forests, a National Grassland, a National Scenic Area, and two National 
Volcanic Monuments, all within the states of Washington and Oregon (Table 1) (USDA Forest Service, 2005). Within the state of Oregon, there are thirteen national forests, including the Deschutes, Fremont, Malheur, Mt. Hood, Ochoco, Rogue River, Siskiyou, Siuslaw, Umatilla, Umpqua, Wallowa-Whitman, Willamette, and Winema National Forests. Within the state of Washington there are a total of six national forests, including Colville, Gifford Pinchot, Mt. Baker-Snoqualmie, Okanogan, Olympic and Wenatchee National Forests. The Columbia River Gorge National Scenic Area is also located on the border of Oregon/Washington (Table 1). Around the Denver, Colorado metropolitan area there are three National Forests and a National Grassland. These include the Arapaho, Pike, and Roosevelt National Forest and Pawnee National Grassland, which is located within Region 2 (Table 2).

Table 1 National Forests in Oregon and Washington

\begin{tabular}{ll}
\hline State & National Forests \\
\hline Oregon & Columbia River Gorge National Scenic Area \\
& Fremont \\
Malheur \\
Mt. Hood \\
Ochoco \\
Rogue River \\
Siskiyou \\
Sisuslaw \\
Umatilla \\
Umpqua \\
Wallowa-Whitman \\
Willamette \\
Winema \\
Colville \\
Gifford Pinchot \\
Mt. Baker-Snoqualmie \\
Okanogan \\
Olympic \\
Wenatchee \\
\hline
\end{tabular}




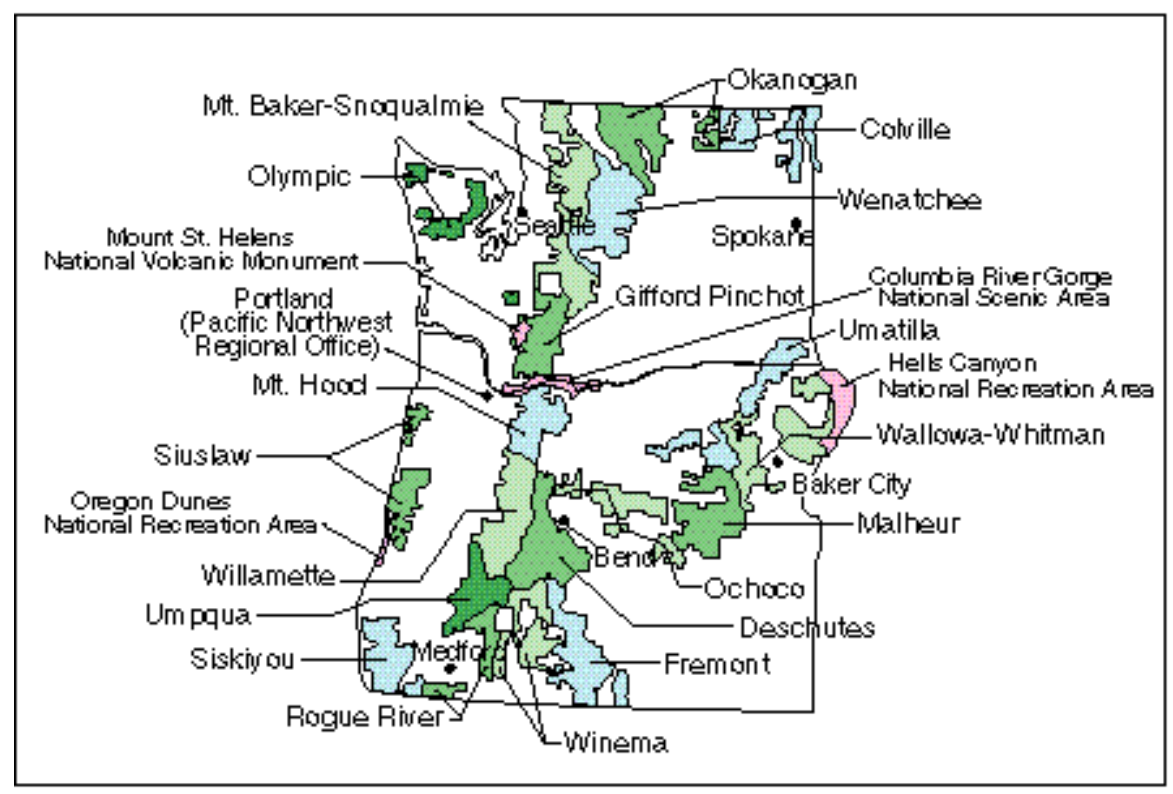

Figure 1: National Forests of Oregon and Washington (USDA Forest Service, 2005)

Table 2 National Forests of Colorado

\begin{tabular}{ll}
\hline State & National Forests \\
\hline Colorado & Arapaho \\
Comanche National Grassland \\
Grand Mesa \\
Gunnison \\
Pawnee National Grassland \\
Pike \\
Rio Grande \\
Roosevelt \\
Routt \\
San Isabel \\
San Juan \\
Uncompahgre \\
White River \\
\hline
\end{tabular}




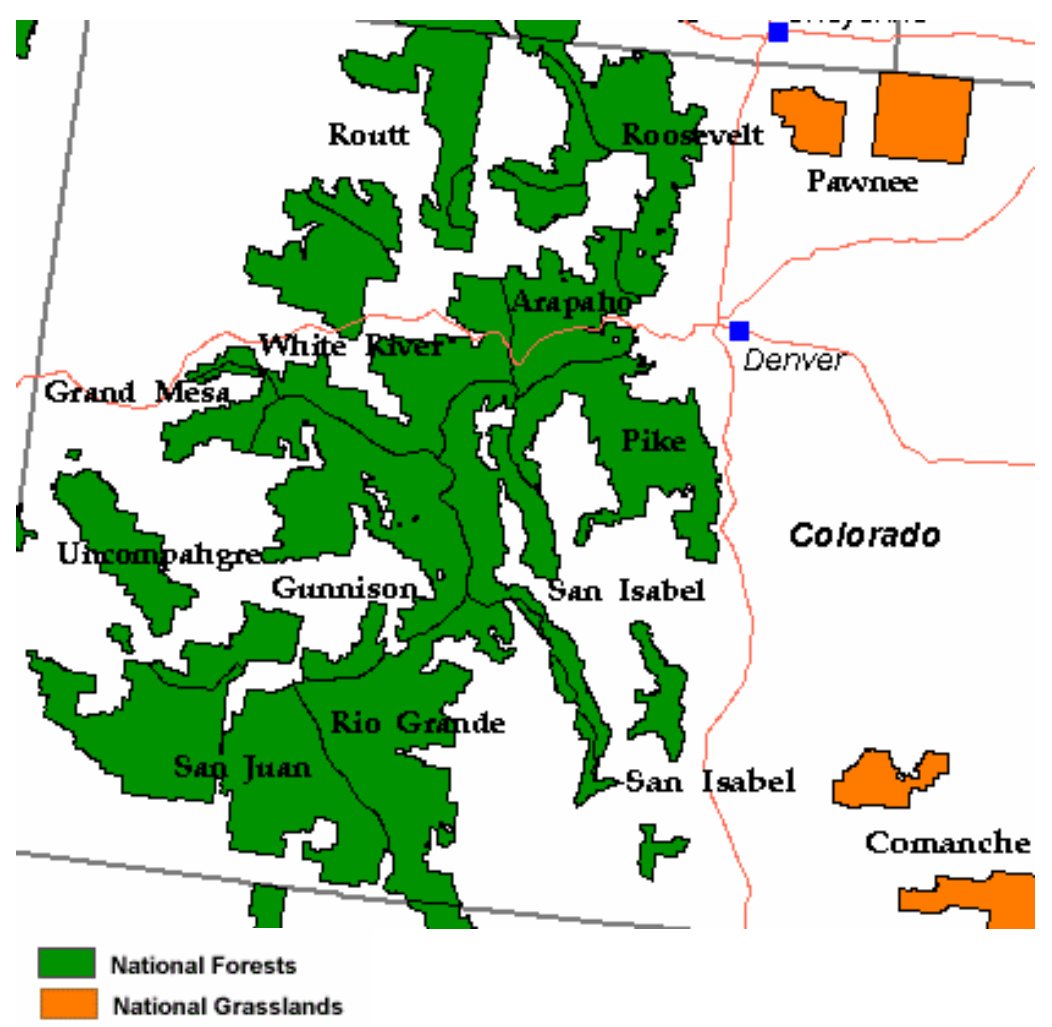

Figure 2: National Forests of Colorado (USDA Forest Service, 2005)

The national forests within the states of Oregon, Washington, and around the Denver metropolitan area provide an abundance of recreational opportunities for visitors, such as hiking, camping, backpacking, fishing, hunting, swimming, bicycling, horseback riding, picnicking, viewing natural features, visiting nature centers on trails, visiting historic and prehistoric sites, motorized and non-motorized water travel, etc. (Farmer, 2004). The vast landscapes of these three western states also provide an ample amount of habitat for a variety of plants and animals, and some of the greatest recreation lands within the country (USDA Forest Service, 2005). For example, Pike and San Isabel National Forests are urban forests located near Denver, Colorado that have fourteen thousand foot peaks and cover over a million acres. These two forested areas are perhaps some of the most diverse national forests found within the United States. Diversity within 
this area exists in many different forms, including the surrounding ecosystems with their unique flora and fauna to the unique cultures found within the communities of Colorado (USDA Forest Service, 2005). Recreationists who visit this area can experience the alpine tundra of the north to the short grass prairies of the east, with much variety in between.

An increase in research on the impact of recreation fees began in 1996, when the United States Congress approved the Recreation Fee Demonstration Program. The recreation fee program, mandated by Congress, required all federal , including the U.S. Forest Service, to develop an initiative for collecting fees from visitors who recreated on federal lands. The purpose behind the fee demonstration program was to provide public lands with an increase of revenue in order to deal with the backlog of maintenance problems on public lands, with the goal of improving the quality of visitor services and enhancing the protection and maintenance of recreational resources (Bengston \& Fan, 2001).

The data analyzed for this study was collected for the USDA Forest Service with the intentions of exploring respondents' customer satisfaction, perceptions of visitor use patterns, and recreation fees. The primary research objective for this study was to obtain a greater understanding of the public's attitudes toward recreation fees.

Additional research objectives were gaining a better understanding of recreation users and their expectations on national forest lands, understanding the price, type, and acceptability of fee systems for our national forest lands, and to better understand the different ways in which individuals desire the information from the recreation fee program. This research study also focused on respondents' willingness to pay for

\footnotetext{
${ }^{1}$ Other federal land agencies under the recreation fee demonstration program (RFDP) included the National Park Service, US Fish and Wildlife Service, and the Bureau of Land Management.
} 
recreation fees, which is the main focus of this thesis. This study focuses on respondents from the states of Oregon and Washington in the Pacific Northwest along with the Denver, Colorado metropolitan area; specifically on respondents' willingness to pay levels with regards to the recreation fee program.

\section{Data Collection}

The data used for this study was initially collected through a random telephone survey of residents within three western states, including Washington, Oregon, and Denver metropolitan area of Colorado; during the period of December 2003 and February 2004, from 4pm-9pm (Pacific Standard Time). The telephone sampling was conducted through a Random-Digit Dial (RDD) process. With this process, a computer is programmed in a way that it selects a number at random and dials it, which helps in finding unlisted telephone numbers within the directory. Thus, those segments of the population who request not to disclose their information in the directory are now included within the survey. The telephone sample numbers were purchased from the Genesys Sampling System (Babbie, 1995; Nyaupane, 2004).

For this study, the population sample was comprised of all adult residents (18years or older) with an operating telephone. The survey did not begin until the interviewer confirmed the respondent's age of being 18-years or older. If the respondents met this minimum criterion, the interviewer proceeded with the recreation survey. However, if the respondents indicated they were 17-years or younger, that individual was asked to give the telephone to somebody within their household who was at least 18years or older. 
If the respondents were eligible regarding their age, they were then notified that the interview consisted of questions pertaining to outdoor recreation activities. Within this study, outdoor recreation was defined as water, land, and snow-based activities. There were several screening questions employed within the survey. Initially, the respondents were asked if there were very interested, somewhat interested, or not at all interested in outdoor recreation activities. Second, the respondents were asked if they had participated in any type of outdoor recreation in the past 12 months. The respondents were also asked if they had ever visited a national forest within Oregon, Washington, or around the Denver, Colorado metropolitan area. If the answer to those questions was yes, the interviewer proceeded to ask the number of times they visited a national forest within Oregon, Washington, or around the Denver, Colorado area during the past 12 months. Finally, users and non-users of the national forest were asked the number of trips they took to non-Forest Service Lands within Oregon, Washington, or Colorado in the past 12 months. Those respondents who had visited a national forest within the three western states in the past 12 months proceeded with the survey following the Forest Service "recreationists" sequence of questions. However, the respondents who did not visit a national forest within Oregon, Washington, or Colorado in the past 12 months continued on with the survey following the "non-recreationists" sequence of questions. The data analyzed for this thesis were only from respondents who were identified as Forest Service "recreationists."

The sampling method yielded a total of 847 completed telephone interviews. The data were collected in two different areas, Oregon-Washington $(\mathrm{n}=366)$ and Denver, Colorado metropolitan area $(\mathrm{n}=481)$. For the purpose of this study, only people who 
reported that they had recreated on a national forest over the past 12 months were included, resulting in 584 useable surveys for this thesis. The overall adjusted response rate for this study was $31.7 \%$ in Oregon-Washington and $31.5 \%$ for the Denver Metropolitan area of Colorado; with an overall response rate of 31.6\% (Nyaupane, 2004). The interview process was completed by the University of Florida's Survey Research Center. The average length of time that it took respondents to complete the 14-page survey was about 40 minutes.

\section{Instrumentation}

This study examined the responses of participants who had recreated within a national forest in Oregon, Washington, or the Denver metropolitan area of Colorado in the past 12 months of being interviewed. The survey instrument included questions pertaining to the respondents' perceptions regarding management strategies, customer satisfaction, and recreation fees. The focus of this thesis is on the section of the survey instrument dealing with recreation fees and respondents' willingness to pay for three different recreational passes, including the Northwest Forest Pass, Daily Pass, and a Golden Eagle Pass.

A total of seven questions were used within the survey to better understand what respondents were willing to pay in order to recreate on the national forests within the three western states. The first item pertained to the respondents' willingness to pay the maximum and appropriate amount for a Northwest Forest Pass. The next item then asked respondents their willingness to pay the maximum and appropriate amount for a Daily Pass, followed by the Golden Eagle Pass. 
A total of five socio-demographic variables were analyzed from the recreation survey. The first variable examined for this study was gender, which is a dichotomous variable. A dichotomous variable is a two-category variable, which in this case is male or female. Next, age was determined at the interval level of measurement, and then that was recoded into five different age categories, including 30 or younger, 31 to 40,41 to 50,51 to 60 , and 61 or older. The next variable analyzed the residence type, which is a nominal level of measurement. Each respondent was given the choice of rural, urban, or suburban residence types that best defined his/her area of current residency. Education was the next variable to be examined, which was also at the nominal level of measurement. The data was recoded into three education categories, including less than an associate's degree, having a associate's or bachelor's degree, and a bachelor's degree or higher. Lastly, income was measured as an ordinal variable. The respondents chose which category best reflected their total 2000 household income, before taxes. The data for this category was recoded into four categories, including $\$ 0$ to $\$ 30,000, \$ 30,001$ to $\$ 50,000, \$ 50,001$ to $\$ 70,000$, and $\$ 70,001$ or higher. 


\section{Testing of the Research Questions}

The following section describes how each research question was analyzed within this study. All questions were analyzed in SPSS (Statistical Package for the Social Sciences, Version 11.5)

\section{$R_{1:}$ What is the socio-demographic makeup of the sample of respondents?}

A total of five socio-demographic variables were analyzed, including gender, age, residence type, income, and education. In order to provide a sample profile of the recreationists, frequencies were analyzed and recorded for these variables; including valid percents, mean, and median.

\section{$\mathbf{R}_{2:}$ What is the maximum amount individuals are willing to pay for a recreational pass?}

To understand the respondents' maximum amount they were willing to pay for the three recreational passes, three analyses were conducted. The analyses were conducted separately for the Northwest Forest Pass, Daily Pass, and the Golden Eagle Pass. In order to provide a sample profile for the willingness to pay the maximum amount for each pass, descriptive frequencies were run and analyzed for each of these variables; including valid percents.

\section{$R_{3:}$ What is the appropriate price individuals are willing to pay for a recreational pass?}

In order to provide a sample profile for the willingness to pay the appropriate price for each pass, frequencies were run and examined for each of these variables; including valid percents. An analysis was conducted for each of the three recreational passes including the Northwest Forest Pass, Daily Pass and the Golden Eagle Pass. 


\section{$\mathbf{R}_{4:}$ Do perceptions of the recreation fee program predict recreationists' maximum amount willing to pay for a recreational pass?}

Three multiple regression tests were run for the willingness to pay the maximum amount for each pass, including the Northwest Forest Pass, Daily Pass, and the Golden Eagle Pass. Prior to the test, the overall independent variables were created with an index including fee equity, social trust within the Forest Service, Fee Acceptance (general and program specific), taxes and fees, and personal impact of fees.

\section{$\mathbf{R}_{5}$ : Do perceptions of the recreation fee program predict recreationists' appropriate price willing to pay for a recreational pass?}

Three multiple regression tests were run for the willingness to pay the appropriate price for each pass, including the Northwest Forest Pass, Daily Pass, and the Golden Eagle Pas. Prior to analyzing the results, the overall independent variables were created with an index with five items. The items included in this index were fee equity, social trust in the Forest Service, fee acceptance (general and program-specific), personal impact of fees, and taxes and fees.

\section{$\mathbf{R}_{6}$ : Are there differences in the willingness to pay model for various visitor segments based on gender, age, residence, education, and income?}

An independent samples t-test was utilized to determine if any significant differences existed in the mean scores between gender and willingness to pay for a recreation pass. The remaining four variables (age, residence, income, and education) were run and examined using one-way analysis of variance (ANOVA).

\section{$R_{7}$ : What is the proper balance between fees and taxes?}

A one-way analysis of variance (ANOVA) was conducted to test whether significant differences existed for the mean scores between willingness to pay and 
recreation user fees and taxes for generating operating funds for our National Forest areas.

\section{Treatment of the Data}

The analysis of the data was conducted through SPSS (Statistical Package for the Social Sciences, Version 11.5). A significance level of .05 was the standard used to test all hypotheses associated with the research questions within this study.

A descriptive profile was created of the respondents within this study, including frequency distributions, means, and valid percents. The independent variables, including fee equity, social trust in the Forest Service, fee acceptance (general and programspecific), taxes and fees, and personal impact of fees were identified a-priori. A total of

five separate indices were developed. A multiple regression model analysis was used as a method of understanding the way a number of independent variables relates to one single variable, which within this study included three different recreational passes. Three separate regression analyses were used to understand the strength of the relationship between the dependent variables (three passes) and the five sets of independent variables. It was hypothesized that these five items would be predictors for the willingness to pay the maximum and appropriate amount for each recreational pass. These five predictor variables were then regressed against the three different recreational passes. An independent samples t-test and one-way analysis of variance (ANOVA) were conducted to examine the differences between the respondents' willingness to pay for a recreational pass and the socio-economic status variables (e.g., gender, age, education, residence type, and income). 


\section{CHAPTER IV}

\section{RESULTS}

The data collected through the telephonic survey provided insight into the willingness to pay levels for the three different passes within the national forests of

Oregon, Washington, and those located near the Denver, Colorado metropolitan area.

The results of the data analysis are presented in seven main sections within this chapter. The first section describes the respondents' basic socio-demographic profile based on the responses obtained during the telephonic survey. The second section answers the research question, "What is the maximum amount individuals are willing to pay for a recreational pass?" The next section is similar to the second research question by discussing the appropriate price individuals are willing to pay for a recreational pass. The chapter goes on to discuss if the maximum amount will predict a recreationist's willingness to pay for a recreational pass, followed by a section focusing on the appropriate price. The following section focuses on five socio-demographic variables, including gender, age, residence, education, and income, and tests whether there are any significant differences within the willingness to pay for three different recreational passes. The final section of this chapter examines whether the respondents agree or disagree that there is a proper balance between fees and taxes for our public lands.

\section{$R_{1:}$ What is the socio-demographic makeup of the sample of respondents?}

The sample for this study consists of 584 useable telephone questionnaires with an adjusted response rate of $31.6 \%$. The respondents within this sample were asked a series of questions regarding their socio-demographic characteristics, including gender, age, income, ethnicity/race, education, residency, household income, and the number of 
children and people currently residing within their household. This thesis will focus on the socio-demographic variables pertaining to gender, age, education, residency, and income (Table 3$)$. This thesis will focus only on respondents $(\mathrm{n}=584)$ who have recreated in the past 12 months on a national forest within three western states, including Oregon, Washington, and near the Denver, Colorado metropolitan area.

A majority of the Forest Service recreationists were males (62.7\%), while over onethird $(37.3 \%)$ were females. Just over one-quarter $(26.8 \%)$ of the respondents were in the age category of 41 to 50 years. Just less than one-quarter of the respondents (22.3\%) were in the age category of 51 to 60 years. Over than two-thirds of the respondents $(37.0 \%)$ were 40 years or younger; while only (13.8\%) of the respondents were 61 years or older. The mean age of the respondents within the age category analysis was 45.7 years. A majority of respondents within this study were Caucasian (87.3\%), with various ethnic minorities being represented within the respondent sample; this represents a higher percentage of minorities than normally seen in outdoor recreation studies.

The next socio-demographic question focuses on the respondents' level of education. Over a quarter of the respondents (27.5\%) reported having their bachelor's degree. One-fifth of the respondents (20.3\%) had completed a graduate or professional degree, while the same proportion (20.3\%) reported taking college level courses but never finished their degree. The following socio-demographic question pertains to the respondents' income levels. The majority of respondents (58.6\%) reported being employed full time, while over one quarter (27.2\%) had an income between $\$ 30,001$ to $\$ 50,000$, and just over one-fifth (21.4\%) of the respondents indicated an income range between $\$ 50,001$ to $\$ 70,000$ per year. The last socio-demographic question analyzed 
pertains to the respondents' residence type, including urban, suburban, and rural. Nearly half of the respondents $(46.2 \%)$ reside in the suburbs, with the remaining respondents living in urban (29.5\%) and rural areas (24.3\%). The socio-demographic profile for the recreation respondents within this study was primarily college educated, Caucasian, and middle aged (Table 3).

Table 3 Socio-demographic Profile of Recreation Respondents

\begin{tabular}{|c|c|c|}
\hline & Frequency & Valid Percent \\
\hline \multicolumn{3}{|l|}{ Gender } \\
\hline Male & 366 & 62.7 \\
\hline Female & 218 & 37.3 \\
\hline Total & 584 & 100.0 \\
\hline \multicolumn{3}{|l|}{ Age } \\
\hline 30 or younger & 102 & 17.6 \\
\hline 31 to 40 & 112 & 19.4 \\
\hline 41 to 50 & 155 & 26.8 \\
\hline 51 to 60 & 129 & 22.3 \\
\hline 61 or older & 80 & 13.8 \\
\hline Total & 578 & 100.0 \\
\hline Mean & 45.68 & \\
\hline \multicolumn{3}{|l|}{ Ethnicity/Race $^{1}$} \\
\hline Hispanic & 24 & 4.2 \\
\hline African-American & 25 & 4.3 \\
\hline Asian American & 31 & 5.3 \\
\hline Hawaiian/Pacific Island & 12 & 2.1 \\
\hline American Indian/Alaska & 39 & 6.7 \\
\hline \multicolumn{3}{|l|}{ Native } \\
\hline Caucasian & 510 & 87.3 \\
\hline Other & 52 & 8.9 \\
\hline \multicolumn{3}{|l|}{ Ethnicity/Race (Recoded) } \\
\hline Caucasian & 462 & 81.5 \\
\hline Non-Caucasian & 105 & 18.5 \\
\hline Total & 567 & 100.0 \\
\hline
\end{tabular}

\footnotetext{
${ }^{1}$ Race alone or in combination with one or more does not add up to 100
} 
Table 3 Socio-demographic Profile of Recreation Respondents (continued)

\begin{tabular}{|c|c|c|}
\hline \multicolumn{3}{|l|}{ Education } \\
\hline Less than $9^{\text {th }}$ grade & 3 & .5 \\
\hline $9^{\text {th }}$ grade to $12^{\text {th }}$ grade, no diploma & 11 & 1.9 \\
\hline High school graduate & 98 & 16.9 \\
\hline Some college, no degree & 118 & 20.3 \\
\hline Associate degree & 60 & 10.3 \\
\hline Bachelor's degree & 160 & 27.5 \\
\hline Graduate or professional degree & 118 & 20.3 \\
\hline Other & 13 & 2.2 \\
\hline Total & 581 & 100.0 \\
\hline \multicolumn{3}{|l|}{ Annual Household Income (before taxes) } \\
\hline Less than 10,000 & 19 & 3.5 \\
\hline 10,001 to 30,000 & 68 & 12.7 \\
\hline 30,001 to 50,000 & 149 & 27.7 \\
\hline 50,001 to 70,000 & 115 & 21.4 \\
\hline 70,001 to 90,000 & 82 & 15.3 \\
\hline 90,001 to 110,000 & 42 & 7.8 \\
\hline 110,001 to 130,000 & 23 & 4.3 \\
\hline 130,001 to 150,000 & 11 & 2.0 \\
\hline 150,001 to 170,000 & 7 & 1.3 \\
\hline 170,001 or more & 21 & 3.9 \\
\hline Total & 537 & 100.0 \\
\hline \multicolumn{3}{|l|}{ Employment } \\
\hline Full time student & 35 & 6.0 \\
\hline Part time student & 5 & .9 \\
\hline Employed full time & 341 & 58.6 \\
\hline Employed part time & 35 & 6.0 \\
\hline Unemployed & 10 & 1.7 \\
\hline Homemaker/caregiver & 28 & 4.8 \\
\hline Retired & 83 & 14.3 \\
\hline Other & 45 & 7.7 \\
\hline Total & 582 & 100.0 \\
\hline \multicolumn{3}{|l|}{ Residence } \\
\hline Urban & 170 & 29.5 \\
\hline Suburban & 266 & 46.2 \\
\hline Rural & 140 & 24.3 \\
\hline Total & 576 & 100.0 \\
\hline
\end{tabular}




\section{$\mathbf{R}_{2}$ : What is the maximum amount individuals are willing to pay for three different recreational passes?}

In order to understand the respondents' familiarity with purchasing a Northwest Forest Pass, Daily Pass, and Golden Eagle Pass, questions were asked regarding their willingness to pay the maximum amount for each recreational pass. With an increase of outdoor recreation in recent years, many federal land areas of the Northwest currently charge a recreational fee to visitors.

The Northwest Forest Pass is a unique pass that allows unlimited access to many of the fee sites located within the states of Washington and Oregon for an annual fee of \$30. The Golden Eagle Pass allows access to many federal lands, including the U.S. Forest Service, National Park Service, Bureau of Land Management, and the U.S. Fish and Wildlife Service managed lands for an annual fee of \$65 (Nyaupane, 2004). The third type of pass is a daily pass that can be purchased from each federal agency for around $\$ 5$ per person.

\section{$\mathbf{R}_{\text {2a: }}$ What is the maximum amount individuals are willing to pay for a Northwest Forest Pass?}

In order to determine the maximum amount respondents were willing to pay for a Northwest Forest Pass, descriptive statistics were run and analyzed including valid percents. The greatest proportion (33.9\%) of the respondents was willing to pay between $\$ 20$ through $\$ 30$ (mean=\$32.60) for the Northwest Forest Pass. Just over one-fifth of the respondents $(20.9 \%)$ were willing to pay a maximum amount between $\$ 50$ through $\$ 65$ for a Northwest Forest Pass. Less than one-fifth (14.7\%) of the respondents were willing to pay a maximum amount between $\$ 35$ through $\$ 45$ (Table 4$)$. The study showed that 
most respondents indicated a willingness to pay slightly more $\$ 32.60$ to purchase the Northwest Forest Pass than the current annual fee price of $\$ 30$.

Table 4 Maximum Amount Willing to Pay for Northwest Forest Pass

\begin{tabular}{ccc}
\hline Maximum Willingness to Pay Variables & Sample & \\
\hline $\begin{array}{l}\text { Maximum - Northwest Forest Pass } \\
\text { (values represented in dollar amounts) }\end{array}$ & Frequency & Valid Percent \\
\hline 0 through 5 & 27 & 15.3 \\
10 through 15 & 16 & 9.0 \\
20 through 30 & 60 & 33.9 \\
35 through 45 & 26 & 14.7 \\
50 through 65 & 37 & 20.9 \\
75 through 120 & 11 & 6.2 \\
Total & 177 & 100.0 \\
Mean & 32.60 & \\
Median & 30.00 & \\
\hline
\end{tabular}

\section{$\mathbf{R}_{2 \mathrm{~b}}$ : What is the maximum amount individuals are willing to pay for a Daily Pass?}

The next question of this study asked respondents to report the maximum amount they would be willing to pay for a daily pass. In order to examine the maximum amount for this pass, descriptive statistics were run and analyzed, including the valid percents. Nearly half of the respondents (41.4\%) reported a willingness to pay between $\$ 4$ through $\$ 7$. Over one-quarter of the respondents (28.4\%) indicated between $\$ 8$ through $\$ 12$, while approximately one-quarter of the respondents (22.9\%) indicated a willingness to pay between $\$ 0$ through $\$ 3$ for a daily pass (Table 5). The mean for the daily pass (\$17.80) was significantly larger than the median $(\$ 5.00)$ since some of the data was skewed toward the maximum amount willing to pay for this pass, because a few respondents indicated a willingness to pay a much higher dollar amount for this pass. 
Table 5 Maximum Amount Willing to Pay for Daily Pass

\begin{tabular}{ccc}
\hline Maximum Willingness to Pay Variables & Sample & \\
\hline $\begin{array}{c}\text { Maximum - Daily Pass } \\
\text { (values represented in dollar amounts) }\end{array}$ & Frequency & Valid Percent \\
\hline 0 through 3 & 112 & \\
4 through 7 & 203 & 22.9 \\
8 through 12 & 139 & 41.4 \\
15 through 25 & 22 & 28.4 \\
35 through 150 & 5 & 4.5 \\
200 through 1000 & 9 & 1.0 \\
Total & 490 & 1.8 \\
Mean & 17.80 & 100.0 \\
Median & 5.00 & \\
\hline
\end{tabular}

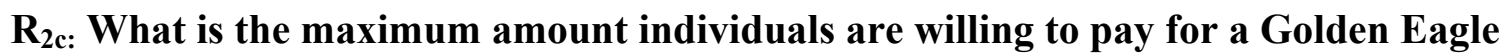
Pass?

The last question focused on the maximum amount respondents were willing to pay for a Golden Eagle Pass. In order to determine the maximum amount respondents were willing to pay for this recreation pass, descriptive statistics were run and analyzed including valid percents. Over one-third of the respondents $(36.0 \%)$ indicated a willingness to pay a maximum amount between $\$ 30$ through $\$ 50$ for the Golden Eagle Pass. A similar proportion of the respondents (30.2\%) reported a willingness to pay between $\$ 55$ through $\$ 75$ for the annual pass (mean $=\$ 57.00)$. A small portion of the respondents (12.6\%) was willing to pay a maximum amount between $\$ 80$ through $\$ 107$ for this pass (Table 6). Most respondents within this study indicated a willingness to pay less than the current annual fee of $\$ 65$ for a Golden Eagle Pass (mean=\$57.00) (Table 6). 
Table 6 Maximum Amount Willing to Pay for Golden Eagle Pass

\begin{tabular}{ccc}
\hline Maximum Willingness to Pay Variables & Sample & \\
\hline $\begin{array}{c}\text { Maximum - Golden Eagle Passport } \\
\text { (values represented in dollar amounts) }\end{array}$ & Frequency & Valid Percent \\
\hline 0 through 5 & 39 & 8.1 \\
8 through 25 & 45 & 9.3 \\
30 through 50 & 174 & 36.0 \\
55 through 75 & 146 & 30.2 \\
80 through 107 & 61 & 12.6 \\
120 through 753 & 18 & 3.7 \\
Total & 483 & 100.0 \\
Mean & 57.00 & \\
Median & 50.00 & \\
\hline
\end{tabular}

\section{$\mathbf{R}_{3}$ : What is the appropriate price individuals are willing to pay for three different recreational passes?}

Since the implementation of recreation fee program within public lands, many recreation managers are facing the decision of how much to charge visitors for recreation use on these lands (Richer \& Christensen, 1999). In many private agencies across the United States, the main objective is to maximize profits by charging the highest price possible. For public agencies, the overall objective is not maximizing profit, but rather to support their cost without dropping the overall number of visitors (Kyle et al., 2002). Several authors have introduced the concept of appropriate price, including Kyle et al. and Richer and Christensen, 1999, which has been considered as a balance between fee revenues and visitor concerns with the ability to pay, fairness, and equity.

This section of the study will provide information for recreation managers about the appropriate price respondents are willing to pay for three different recreational passes. In order to understand the respondents' familiarity with purchasing these three passes, including the Northwest Forest Pass, Daily Pass, and Golden Eagle Pass, questions were asked regarding their willingness to pay an appropriate price for each pass. In order to 
determine the appropriate price respondents were willing to pay for three different passes, descriptive statistics were run and analyzed for each item; along with valid percents.

\section{$\mathbf{R}_{3 \mathrm{a}}$ : What is the appropriate price individuals are willing to pay for a Northwest Forest Pass?}

Nearly half of the respondents $(42.0 \%)$ were willing to pay an appropriate price between $\$ 20$ through $\$ 35$ for a Northwest Forest Pass $($ mean $=\$ 29.85)$. Over one-quarter of the respondents $(29.0 \%)$ indicated a willingness to pay between $\$ 40$ through $\$ 55$. The remainder of the respondents (22.1\%) reported an appropriate amount of $\$ 18$ and below, with a small minority of respondents $(6.8 \%)$ willing to pay between $\$ 60$ through $\$ 80$

(Table 7). The U.S. Forest Service currently charges an annual fee of $\$ 30$ to visitors for a Northwest Forest Pass, which is an appropriate price according to the mean price (\$29.85) from this study.

Table 7 Appropriate Price Willing to Pay for Northwest Forest Pass

\begin{tabular}{ccc}
\hline Appropriate Willingness to Pay Variables & Sample & \\
\hline $\begin{array}{c}\text { Appropriate }- \text { Northwest Forest Pass } \\
\text { (values represented in dollar amounts) }\end{array}$ & Frequency & Valid Percent \\
\hline 0 through 5 & 24 & 13.6 \\
10 through 18 & 15 & 8.5 \\
20 through 35 & 74 & 42.0 \\
40 through 55 & 51 & 29.0 \\
60 through 80 & 12 & 6.8 \\
Total & 176 & 100.0 \\
Mean & 29.85 & \\
Median & 30.00 & \\
\hline
\end{tabular}




\section{$R_{3 b}$ : What is the appropriate price individuals are willing to pay for a Daily Pass?}

The next appropriate price question pertained to the respondent's willingness to pay for a daily pass. Nearly half of the respondents indicated between $\$ 4$ through $\$ 7$ as an appropriate price. A large proportion of respondents (39.7\%) reported an appropriate price between $\$ 0$ through $\$ 3$, and around one-third (13.0\%) of the respondents indicated a willingness to pay between $\$ 8$ through $\$ 18($ mean $=\$ 8.27)($ Table 8$)$.

Table 8 Appropriate Price Willing to Pay for Daily Pass

\begin{tabular}{lcc}
\hline Appropriate Willingness to Pay Variables & Sample & \\
\hline $\begin{array}{l}\text { Appropriate }- \text { Daily Pass } \\
\text { (values represented in dollar amounts) }\end{array}$ & Frequency & Valid Percent \\
\hline 0 through 3 & 190 & 39.7 \\
4 through 7 & 212 & 44.4 \\
8 through 18 & 62 & 13.0 \\
20 through 100 & 9 & 1.9 \\
150 through 700 & 5 & 1.0 \\
Total & 478 & 100.0 \\
Mean & 8.27 & \\
Median & 5.00 & \\
\hline
\end{tabular}

$\mathbf{R}_{3 \mathrm{c} \text { : }}$ What is the appropriate price individuals are willing to pay for a Golden Eagle Pass?

The last appropriate price question pertained to the respondents willingness to pay for a Golden Eagle Pass. Nearly one-third of the respondents (32.4\%) indicated a willingness to pay the appropriate price between $\$ 45$ through $\$ 60($ mean $=\$ 51.90)$. Slightly over one-quarter of the respondents $(27.4 \%)$ indicated a willingness to pay between $\$ 63$ through $\$ 80$. A little less than a fifth of the respondents (17.1\%) reported an appropriate price between $\$ 25$ through $\$ 40$. Federal agencies are currently charging an annual fee of $\$ 65$ for the Golden Eagle Pass, while this study found that $\$ 51.90$ was an appropriate mean price. 
Table 9 Appropriate Price Willing to Pay for Golden Eagle Pass

\begin{tabular}{ccc}
\hline Appropriate Willingness to Pay Variables & Sample & \\
\hline $\begin{array}{l}\text { Appropriate }- \text { Golden Eagle Passport } \\
\text { (values represented in dollar amounts) }\end{array}$ & Frequency & Valid Percent \\
\hline 0 through 5 & & \\
8 through 20 & 38 & 8.0 \\
25 through 40 & 31 & 6.5 \\
45 through 60 & 81 & 17.1 \\
63 through 80 & 154 & 32.4 \\
85 through 560 & 130 & 27.4 \\
Total & 41 & 8.6 \\
Mean & 475 & 100.0 \\
Median & 51.90 & \\
\hline
\end{tabular}

\section{$\mathbf{R}_{4}$ : Do perceptions of the recreation fee program predict recreationists' maximum amount willing to pay for a recreational pass?}

A series of multiple regression analyses were conducted to determine the strength

of the relationships between five independent variables and three dependent recreational pass variables, including the Northwest Forest Pass, Daily Pass, and the Golden Eagle Pass. For each dependent variable, a multiple regression model was conducted for the willingness to pay the maximum amount for each pass. These dependent variables were regressed against five independent variables, including the equity of fees, social trust in the Forest Service, acceptance of fees (general and program specific), personal impact of fees, and taxes associated with fees. In order to determine the relationship between the independent and dependent variables, a total of three regression models (maximum amount willing to pay for each pass) were run and analyzed. 


\section{$\mathbf{R}_{4 a}$ : Do perceptions of the recreation fee program predict recreationists' maximum amount willing to pay for a Northwest Forest Pass?}

The Northwest Forest Pass was the first dependent variable to be run and analyzed against the five independent variables (Table 10). The tests results revealed two items as being significant predictors in willingness to pay the maximum amount for a Northwest Forest Pass. The strongest predictor was fee acceptance $($ Beta $=.494)$, followed by taxes and fees $($ Beta $=.194)$. This model accounted for about $39 \%$ of the variance in the maximum amount willing to pay for a Northwest Forest Pass.

Table 10 Multiple Regression Results for the Relationship Between Predictor Variables and Willingness to Pay the Maximum Amount for Northwest Forest Pass

\begin{tabular}{lcccc}
\hline & & \multicolumn{2}{c}{ Standardized Coefficients } & \\
\cline { 3 - 4 } Variables & Pearson $r$ & Beta & $R^{2}$ & $F$ \\
\hline Fee Equity & $-.284 * * *$ & $\mathrm{~ns}$ & $.386^{* * *}$ & $21.403 * * *$ \\
Social Trust in the Forest & -.070 & $\mathrm{~ns}$ & & \\
Service & $.594 * * *$ & $.494 * * *$ & \\
Fee Acceptance & $-.323 * * *$ & $\mathrm{~ns}$ & \\
Personal Impact of Fees & $-.404 * * *$ & $.194 * *$ & \\
Taxes and Fees & & .01 level, *** significant $\alpha<.001$ level
\end{tabular}

\section{$\mathbf{R}_{4 b \text { : }}$ Do perceptions of the recreation fee program predict recreationists' maximum amount willing to pay for a Daily Pass?}

The next regression model tested the five independent variables against the maximum amount willing to pay for a Daily Pass. The test results revealed no significance with this regression model. Nonetheless, this finding of no significance across all predictors represents an important finding within this research study (Table 11). 
Table 11 Multiple Regression Results for the Relationship Between Predictor Variables and Willingness to Pay the Maximum Amount for Daily Pass

\begin{tabular}{lcccc}
\hline & & \multicolumn{2}{c}{ Standardized Coefficients } & \\
\cline { 3 - 4 } Variables & Pearson $r$ & Beta & $R^{2}$ & $F$ \\
\hline Fee Equity & -.077 & $\mathrm{~ns}$ & $\mathrm{~ns}$ & $\mathrm{~ns}$ \\
Social Trust in the Forest & -.042 & $\mathrm{~ns}$ & & \\
Service & .033 & $\mathrm{~ns}$ & \\
Fee Acceptance & -.086 & $\mathrm{~ns}$ & \\
Personal Impact of Fees & -.078 & $\mathrm{~ns}$ & \\
Taxes and Fees & & & \\
\hline
\end{tabular}

$\mathbf{R}_{4 \mathrm{c}}$ Do perceptions of the recreation fee program predict recreationists' maximum amount willing to pay for a Golden Eagle Pass?

The third regression model tested the five independent variables against the maximum amount willing to pay for a Golden Eagle Pass. The tests results revealed two significant independent predictors, including fee acceptance (Beta=.211) and personal impact of fees $($ Beta $=-.128)$ with fee acceptance being the strongest predictor variable. This model accounted for about $12 \%$ of the variance in the maximum amount willing to pay for a Golden Eagle Pass (Table 12). 
Table 12 Multiple Regression Results for the Relationship Between Predictor Variables and Willingness to Pay the Maximum Amount for Golden Eagle Pass

\begin{tabular}{lcccc}
\hline & & \multicolumn{2}{c}{ Standardized Coefficients } & \\
\cline { 3 - 4 } Variables & Pearson $r$ & Beta & $R^{2}$ & $F$ \\
\hline Fee Equity & $-.183^{* * *}$ & $\mathrm{~ns}$ & $.124 * * *$ & $13.468^{* * *}$ \\
Social Trust in the Forest & -.047 & $\mathrm{~ns}$ & & \\
Service & $.312^{* * *}$ & $.211 * * *$ & \\
Fee Acceptance & $-.273^{* * *}$ & $-.128^{*}$ & \\
Personal Impact of Fees & $-.206^{* * *}$ & $\mathrm{~ns}$ & \\
Taxes and Fees & & & \\
\hline
\end{tabular}

$*$ significant $\alpha<.05$ level, $* *$ significant $\alpha<.01$ level, $* * *$ significant $\alpha<.001$ level

Overall, there were five independent variable items hypothesized to be predictors in the willingness to pay the maximum amount for three recreational passes. Only three variables proved to be predictors. Fee acceptance (general and program-specific) proved to be the strongest predictor variable with willingness to pay the maximum amount for the Northwest Forest Pass $($ Beta $=.494)$ and a Golden Eagle Pass $($ Beta=.211). Taxes and fees $($ Beta $=.194)$ was the next strongest predictor for the Northwest Forest Pass followed

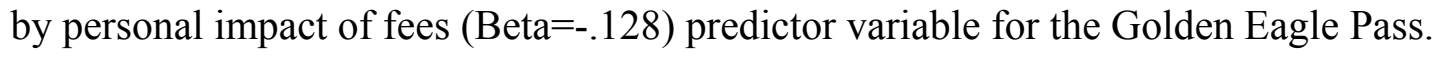

\section{$R_{5:}$ Do perceptions of the recreation fee program predict recreationists' appropriate price willing to pay for a recreational pass?}

A series of multiple regression analysis were conducted to determine the strength of the relationships between five independent variables and three dependent recreational pass variables, including the Northwest Forest Pass, Daily Pass, and the Golden Eagle Pass. For each dependent variable, a multiple regression model was conducted for the willingness to pay the appropriate price for each pass. These dependent variables were regressed against five different independent variables, including the equity of fees, social trust in the Forest Service, acceptance of fees (general and program specific), personal 
impact of fees, and taxes associated with fees. In order to determine the relationship between the independent and dependent variables, a total of three regression models (appropriate price willing to pay for each pass) were run and analyzed.

\section{$R_{5 a}$ : Do perceptions of the recreation fee program predict recreationists' appropriate price willing to pay for a Northwest Forest Pass?}

The Northwest Forest Pass was the first dependent variable to be run and analyzed against the five independent variables. The test results for this pass revealed three items as significant predictors in willingness to pay the appropriate price for a Northwest Forest Pass. The strongest predictor variable was fee acceptance (Beta $=.438$ ); followed by social trust in the Forest Service (Beta=.132), and then taxes and fees (Beta $=-.208)$. This model accounted for $38 \%$ of the variance in the appropriate price willing to pay for a Northwest Forest Pass (Table 13).

Table 13 Multiple Regression Results for the Relationship Between Predictor Variables and Willingness to Pay an Appropriate Price for Northwest Forest Pass

\begin{tabular}{lcccc}
\hline & & \multicolumn{2}{c}{ Standardized Coefficients } & \multirow{2}{*}{ Variables } \\
\cline { 3 - 4 } & Pearson $r$ & Beta & $R^{2}$ & $F$ \\
\hline Fee Equity & $-.305^{* * *}$ & $\mathrm{~ns}$ & $.377^{* * * *}$ & $20.425^{* * *}$ \\
Social Trust in the Forest & -.033 & $.132^{*}$ & & \\
Service & $.571^{* * *}$ & $.438^{* *}$ & & \\
Fee Acceptance & $-.361^{* * *}$ & $\mathrm{~ns}$ & \\
Personal Impact of Fees & $-.406^{* * *}$ & $-.208^{* *}$ & \\
Taxes and Fees & & & \\
\hline * significant $\alpha<.05$ level, ** significant $\alpha<.01$ level, *** significant $\alpha<.001$ level
\end{tabular}




\section{$\mathbf{R}_{5 \mathrm{~b} \text { : }}$ Do perceptions of the recreation fee program predict recreationists' appropriate price willing to pay for a Daily Pass?}

The next regression model tested the five independent variables against the appropriate price willing to pay for a Daily Pass. The test results within this study revealed no significance across any of these variables (Table 14).

Table 14 Multiple Regression Results for the Relationship Between Predictor Variables and Willingness to Pay an Appropriate Price for Daily Pass

\begin{tabular}{lcccc}
\hline & & \multicolumn{2}{c}{ Standardized Coefficients } & \\
\cline { 3 - 4 } Variables & Pearson $r$ & Beta & $R^{2}$ & $F$ \\
\hline Fee Equity & -.056 & $\mathrm{~ns}$ & $\mathrm{Ns}$ & $\mathrm{ns}$ \\
Social Trust in the Forest & -.066 & $\mathrm{~ns}$ & \\
Service & .060 & $\mathrm{~ns}$ & \\
Fee Acceptance & -.028 & $\mathrm{~ns}$ & \\
Personal Impact of Fees & -.056 & $\mathrm{~ns}$ & \\
Taxes and Fees & & & \\
\hline
\end{tabular}

$\mathbf{R}_{5 \mathrm{c} \text { : }}$ Do perceptions of the recreation fee program predict recreationists' appropriate price willing to pay for a Golden Eagle Pass?

The final regression model pertained to the appropriate price respondents were willing to pay for a Golden Eagle Pass. The test results revealed two independent predictors as significant, including fee acceptance $($ Beta $=.325)$ and taxes and fees $($ Beta $=.178)$ with fee acceptance being the strongest predictor. This model accounted for about $21 \%$ of the variance in the appropriate amount willing to pay for a Golden Eagle Pass. 
Table 15 Multiple Regression Results for the Relationship Between Predictor Variables and Willingness to Pay an Appropriate Price for Golden Eagle Pass

\begin{tabular}{lcccc}
\hline & & \multicolumn{2}{c}{ Standardized Coefficients } & \multirow{2}{*}{ Variables } \\
\cline { 3 - 4 } & Pearson $r$ & Beta & $R^{2}$ & \\
\hline Fee Equity & $-.195 * * *$ & $\mathrm{~ns}$ & $.208 * * *$ & $24.437 * * *$ \\
Social Trust in the Forest & -.080 & $\mathrm{~ns}$ & & \\
Service & $.417 * * *$ & $.325^{* *}$ & \\
Fee Acceptance & $-.298^{* * *}$ & $\mathrm{~ns}$ & \\
Personal Impact of Fees & $-.302 * * *$ & $-.178^{* *}$ & \\
Taxes and Fees & & & \\
\hline$*$ significant $\alpha<.05$ level $* *$ significant $\alpha<01$ level $* * *$ significant $\alpha<001$ level
\end{tabular}

$*$ significant $\alpha<.05$ level, $* *$ significant $\alpha<.01$ level, $* * *$ significant $\alpha<.001$ level

Overall, there were five independent variable items hypothesized to be predictors in the willingness to pay the appropriate price for three recreational passes. Three out of the five independent variables proved to be predictors. Fee acceptance (general and program specific) proved to be the strongest predictors for the willingness to pay the appropriate price for the Northwest Forest Pass $($ Beta $=.438)$ and a Golden Eagle Pass (Beta $=.325)$. The next strongest predictor was social trust in the Forest Service (Beta $=.132)$ for the Northwest Forest Pass followed by taxes and fees (Beta $=-.208$, Beta $=-.178)$ for the Northwest Forest Pass and Golden Eagle Pass.

\section{$\mathbf{R}_{\mathbf{6}}$ : Are there differences in willingness to pay for various visitor segments based on gender, age, residence, income, and education?}

In order to examine the strength of relationships between willingness to pay for a recreational pass and five socio-demographic variables, an independent t-test and a series of one-way analysis of variance was utilized. 


\section{$\mathbf{R}_{6 \mathrm{a}}$ : Are there differences in the willingness to pay model for gender?}

An independent sample t-test was utilized to determine if there were any

significant differences in the mean scores of willingness to pay for a recreational pass by gender. The test results revealed a significant difference between males and females for the willingness to pay the appropriate price for a Northwest Forest Pass. The mean score for males willing to pay an appropriate price for a Northwest Forest Pass was \$27.27, while the mean score for females of this same question was $\$ 34.56$. Males were willing to pay less for an appropriate price for a Northwest Forest Pass than females, demonstrating a difference at the $\mathrm{p}<.01$ level $(\mathrm{t}=-2.566, \mathrm{df}=174)$ (Table 16).

Table 16: Independent Samples t-test Results of Willingness to Pay by Gender

\begin{tabular}{|c|c|c|c|c|}
\hline Gender & Male & Female & df & $\mathrm{t}$ \\
\hline $\begin{array}{l}\text { What is the maximum amount you would be } \\
\text { willing to pay for this type of pass-Daily } \\
\text { Pass }\end{array}$ & 15.82 & 21.26 & 488 & -.663 \\
\hline $\begin{array}{l}\text { What do you think is the appropriate price to } \\
\text { charge for such a pass - Daily Pass }\end{array}$ & 5.99 & 12.37 & 476 & -1.827 \\
\hline $\begin{array}{l}\text { What is the maximum amount you would be } \\
\text { willing to pay for this type of pass - } \\
\text { Northwest Forest Pass }\end{array}$ & 32.27 & 33.19 & 175 & -.272 \\
\hline $\begin{array}{l}\text { What do you think is the appropriate price to } \\
\text { charge for such a pass - Northwest Forest } \\
\text { Pass }\end{array}$ & 27.27 & 34.36 & 174 & $-2.566 * *$ \\
\hline $\begin{array}{l}\text { What is the maximum amount you would be } \\
\text { willing to pay for this type of pass - Golden } \\
\text { Eagle Pass }\end{array}$ & 57.69 & 55.83 & 481 & .442 \\
\hline $\begin{array}{l}\text { What do you think is the appropriate price to } \\
\text { charge for such a pass - Golden Eagle Pass }\end{array}$ & 49.71 & 55.77 & 473 & -1.819 \\
\hline
\end{tabular}

** significant $\alpha<.01$ level

\section{$\mathbf{R}_{6 b}$ : Are there differences in the willingness to pay model for age?}

A one-way analysis of variance was used to determine whether any significant differences existed across the mean scores for the age group socio-demographic variable. 
The one-way analysis of variance for the age group category revealed no significant differences in willingness to pay for three recreational passes (Table 17).

Table 17: Analysis of Variance for Willingness to Pay by Age

\begin{tabular}{|c|c|c|c|c|c|c|}
\hline Age & $\begin{array}{c}30 \text { or } \\
\text { younger }\end{array}$ & 31 to 40 & 41 to 50 & 51 to 60 & $\begin{array}{l}61 \text { or } \\
\text { older }\end{array}$ & F-value \\
\hline $\begin{array}{l}\text { Maximum amount } \\
\text { willing to pay for - } \\
\text { Daily Pass }\end{array}$ & 29.83 & 26.62 & 10.14 & 6.95 & 20.16 & 1.324 \\
\hline $\begin{array}{l}\text { Appropriate price to } \\
\text { charge for such a pass } \\
\text { - Daily Pass }\end{array}$ & 17.84 & 5.10 & 6.32 & 5.94 & 7.17 & 1.844 \\
\hline $\begin{array}{l}\text { Maximum amount } \\
\text { willing to pay for - } \\
\text { Northwest Forest Pass }\end{array}$ & 39.51 & 30.78 & 30.56 & 32.41 & 31.35 & 1.102 \\
\hline $\begin{array}{l}\text { Appropriate price to } \\
\text { charge for such a pass } \\
\text { - Northwest Forest } \\
\text { Pass }\end{array}$ & 33.80 & 28.92 & 28.14 & 30.71 & 29.38 & .584 \\
\hline $\begin{array}{l}\text { Maximum amount } \\
\text { willing to pay for - } \\
\text { Golden Eagle Pass }\end{array}$ & 60.84 & 58.00 & 63.27 & 50.83 & 47.27 & 2.009 \\
\hline $\begin{array}{l}\text { Appropriate price to } \\
\text { charge for such a pass } \\
\text { - Golden Eagle Pass }\end{array}$ & 54.78 & 52.76 & 52.44 & 52.56 & 45.08 & .749 \\
\hline
\end{tabular}

\section{$\mathbf{R}_{6 c}:$ Are there differences in the willingness to pay model for residence type?}

Next, a one-way analysis of variance was used to determine if any significance existed across the mean scores by the category of residence type, including urban, suburban, and rural. The ANOVA test results revealed a significant difference with the appropriate price to charge for a Golden Eagle Pass $(\mathrm{F}=5.342)$ by residence type. The respondents living in suburban areas (mean=57.15) showed the highest mean for the appropriate price to charge for a Golden Eagle Pass; followed by urban (mean=49.68), and rural (mean=44.29) (Table 18). 
Table 18: Analysis of Variance for Willingness to Pay by Residence

\begin{tabular}{|c|c|c|c|c|}
\hline Residence & Urban (a) & Suburban (b) & Rural (c) & F-value \\
\hline $\begin{array}{l}\text { Maximum amount willing to pay } \\
\text { for - Daily Pass }\end{array}$ & 31.60 & 9.84 & 16.44 & 2.752 \\
\hline $\begin{array}{l}\text { Appropriate price to charge for } \\
\text { such a pass - Daily Pass }\end{array}$ & 11.14 & 6.88 & 7.17 & .627 \\
\hline $\begin{array}{l}\text { Maximum amount willing to pay } \\
\text { for - Northwest Forest Pass }\end{array}$ & 34.10 & 34.71 & 30.51 & .710 \\
\hline $\begin{array}{l}\text { Appropriate price to charge for } \\
\text { such a pass - Northwest Forest } \\
\text { Pass }\end{array}$ & 31.00 & 32.35 & 27.65 & 1.172 \\
\hline $\begin{array}{l}\text { Maximum amount willing to pay } \\
\text { for - Golden Eagle Pass }\end{array}$ & 55.55 & 59.27 & 55.02 & .462 \\
\hline $\begin{array}{l}\text { Appropriate price to charge for } \\
\text { such a pass - Golden Eagle } \\
\text { Pass }\end{array}$ & 49.68 & 57.15 & 44.29 & $5.342 * *$ \\
\hline
\end{tabular}

\section{$\mathbf{R}_{6 \mathrm{~d}}$ : Are there differences in the willingness to pay model for income?}

One-way analysis of variance was used to identify the effect of four different income levels, including less than $\$ 30,000, \$ 30,001$ to $\$ 50,000, \$ 50,001$ to $\$ 70,000$, and $\$ 70,001$ or higher, have on the six different willingness to pay variables. The test results revealed no significant differences in the willingness to pay by the mean scores for the four different income levels (Table 19). 
Table 19: Analysis of Variance for Willingness to Pay by Income

\begin{tabular}{lccccc}
\hline \multicolumn{1}{c}{ Income } & $\begin{array}{c}\text { Less than } \\
30,000\end{array}$ & $\begin{array}{c}30,001 \text { to } \\
50,000\end{array}$ & $\begin{array}{c}50,001 \text { to } \\
70,000\end{array}$ & $\begin{array}{c}70,001 \text { or } \\
\text { higher }\end{array}$ & F-value \\
\hline $\begin{array}{l}\text { Maximum amount willing to } \\
\text { pay for - Daily Pass }\end{array}$ & 7.99 & 31.48 & 7.64 & 19.83 & 1.595 \\
$\begin{array}{l}\text { Appropriate price to charge } \\
\quad \text { for such a pass - Daily }\end{array}$ & 6.54 & 13.71 & 6.00 & 5.66 & 1.281 \\
$\quad \begin{array}{l}\text { Pass } \\
\text { Maximum amount willing to } \\
\text { pay for - Northwest Forest } \\
\quad \text { Pass }\end{array}$ & 31.77 & 32.93 & 31.56 & 36.00 & .377 \\
$\begin{array}{l}\text { Appropriate price to charge } \\
\text { for such a pass - }\end{array}$ & 30.06 & 31.28 & 26.81 & 31.52 & .551 \\
$\quad \begin{array}{l}\text { Northwest Forest Pass } \\
\text { Maximum amount willing to } \\
\text { pay for - Golden Eagle }\end{array}$ & 49.29 & 55.40 & 64.88 & 60.07 & 1.812 \\
$\quad \begin{array}{l}\text { Pass } \\
\begin{array}{l}\text { Appropriate price to charge } \\
\text { for such a pass - Golden } \\
\text { Eagle Pass }\end{array}\end{array}$ & 47.66 & 55.94 & 50.45 & 54.27 & .993 \\
\hline
\end{tabular}

\section{$\mathbf{R}_{6 \mathrm{e}}$ : Are there differences in the willingness to pay model by education?}

The dependency of willingness to pay on education type, including less than associate's degree, associate's or bachelor's degree, and graduate degree or higher, was also examined. Three variables were run and analyzed against the six different recreational pass variables for the willingness to pay. The ANOVA results revealed a significant difference $(\alpha<.05)$ with the maximum amount willing to pay for a Golden Eagle Pass $(\mathrm{F}=3.918)$. A graduate degree or higher $(\mathrm{F}=65.43)$ reported the highest mean score for willingness to pay the maximum, followed by an associates or bachelors degree $(F=57.51)$, and less than associates degree $(F=51.82)$ (Table 20). The results of this study showed that the more education respondents reported, the higher their willing to pay the maximum amount for a Golden Eagle Pass. 
Table 20: Analysis of Variance for Willingness to Pay by Education

\begin{tabular}{|c|c|c|c|c|}
\hline Education & $\begin{array}{l}\text { Less than } \\
\text { Associates } \\
\text { Degree (a) }\end{array}$ & $\begin{array}{l}\text { Associates/ } \\
\text { Bachelors } \\
\text { Degree (b) }\end{array}$ & $\begin{array}{l}\text { Graduate } \\
\text { Degree or } \\
\text { higher }(\mathrm{c})\end{array}$ & F-Value \\
\hline $\begin{array}{l}\text { Maximum amount willing to pay } \\
\text { for - Daily Pass }\end{array}$ & 9.87 & 23.57 & 21.82 & 1.314 \\
\hline $\begin{array}{l}\text { Appropriate price to charge for } \\
\text { such a pass - Daily Pass }\end{array}$ & 7.50 & 9.97 & 6.31 & .381 \\
\hline $\begin{array}{l}\text { Maximum amount willing to pay } \\
\text { for - Northwest Forest Pass }\end{array}$ & 31.32 & 33.43 & 34.90 & .356 \\
\hline $\begin{array}{l}\text { Appropriate price to charge for } \\
\text { such a pass - Northwest Forest } \\
\text { Pass }\end{array}$ & 29.08 & 31.30 & 29.58 & .287 \\
\hline $\begin{array}{l}\text { Maximum amount willing to pay } \\
\text { for - Golden Eagle Pass }\end{array}$ & 51.82 & 57.51 & 65.43 & $3.198 * 1$ \\
\hline $\begin{array}{l}\text { Appropriate price to charge for } \\
\text { such a pass - Golden Eagle } \\
\text { Pass }\end{array}$ & 48.53 & 54.90 & 52.93 & .208 \\
\hline
\end{tabular}

\section{$R_{7}$ : What is the proper balance between fees and taxes?}

A one-way analysis of variance was used to determine if any significant differences existed between the mean scores of willingness to pay for three recreational passes against user fees and taxes categories.

A total of six one-way analysis of variance tests were run and analyzed within this section. The test results revealed five out of the six items as being significant. The ANOVA results for the proper balance of fees and taxes with the maximum amount individuals would be willing to pay for a daily pass proved to be the only insignificant item. The highest means were found within the category that "our national forests should be funded equally from taxes and fees," including the willingness to pay for a Golden Eagle Pass $($ mean $=65.35)$; followed by willingness to pay the maximum amount for a Northwest Forest Pass $($ mean $=41.33)$, and willingness to pay the appropriate price for a Northwest Forest Pass $($ mean $=38.04)$. The highest mean scores for the category that 
"our national forests should be funded entirely from recreation fees" was willingness to pay an appropriate price for a Golden Eagle Pass $($ mean $=63.86)$ and daily pass $($ mean $=$ 18.33). These individuals who support recreation fees on our national forests will likely have a greater willingness to pay for these recreational areas.

Table 21: Analysis of Variance for Willingness to Pay by Fees and Taxes

\begin{tabular}{|c|c|c|c|c|}
\hline Taxes and User Fees & $\begin{array}{l}\text { Entirely from } \\
\text { fees (a) }\end{array}$ & $\begin{array}{l}\text { Equally from } \\
\text { taxes and fees } \\
\text { (b) }\end{array}$ & $\begin{array}{l}\text { Entirely from } \\
\text { Taxes (c) }\end{array}$ & F-Value \\
\hline $\begin{array}{l}\text { What is the maximum amount } \\
\text { you would be willing to pay fo } \\
\text { this type of pass- Daily Pass }\end{array}$ & 15.78 & 17.85 & 23.11 & .190 \\
\hline $\begin{array}{l}\text { What is the appropriate amount } \\
\text { you would be willing to pay fo } \\
\text { this type of pass - Daily Pass }\end{array}$ & or & 6.47 & 18.33 & $3.615 * 1$ \\
\hline $\begin{array}{l}\text { What is the maximum amount } \\
\text { you would be willing to pay fo } \\
\text { this type of pass - Northwest } \\
\text { Forest Pass }\end{array}$ & or & 41.33 & 36.85 & $16.473 *^{2}$ \\
\hline $\begin{array}{l}\text { What is the appropriate amount } \\
\text { you would be willing to pay fo } \\
\text { this type of pass - Northwest } \\
\text { Forest Pass }\end{array}$ & or & 38.04 & 33.19 & $26.441 *^{3}$ \\
\hline $\begin{array}{l}\text { What is the maximum amount } \\
\text { you would be willing to pay fo } \\
\text { this type of pass - Golden } \\
\text { Eagle Pass }\end{array}$ & or & 65.35 & 61.09 & $11.360 * 4$ \\
\hline $\begin{array}{l}\text { What is the appropriate amount } \\
\text { you would be willing to pay fo } \\
\text { this type of pass - Golden } \\
\text { Eagle Pass }\end{array}$ & or & 58.88 & 63.86 & $27.597 *^{5}$ \\
\hline $\begin{array}{l}* \text { significant } \alpha<.05 \text { level } \\
\text { Scheffe Post Hoc Analysis }(\alpha \leq .05)\end{array}$ & & & & \\
\hline $\begin{array}{l}\text { 1. } \mathrm{a} \text { and } \mathrm{c} \text { are different } \\
\mathrm{b} \text { and } \mathrm{c} \text { are different } \\
\mathrm{c} \text { is different from } \mathrm{a} \text { and } \mathrm{b}\end{array}$ & \multicolumn{2}{|c|}{$\begin{array}{l}\text { 2. } a \text { is different from } b \text { and } c \\
b \text { and a are different } \\
\mathrm{c} \text { and } \mathrm{a} \text { are different }\end{array}$} & \multirow{2}{*}{\multicolumn{2}{|c|}{$\begin{array}{l}\text { 3. } \mathrm{a} \text { is different from } \mathrm{b} \text { and } \mathrm{c} \\
\mathrm{b} \text { and a are different } \\
\mathrm{c} \text { and a are different }\end{array}$}} \\
\hline $\begin{array}{l}\text { 4. } a \text { and } b \text { are different } \\
b \text { and } a \text { are different }\end{array}$ & \multicolumn{2}{|c|}{$\begin{array}{l}\text { 5. } \mathrm{a} \text { is different from } \mathrm{b} \text { and } \mathrm{c} \\
\mathrm{b} \text { and } \mathrm{a} \text { are different } \\
\mathrm{c} \text { and } \mathrm{a} \text { are different }\end{array}$} & & \\
\hline
\end{tabular}




\section{CHAPTER V}

\section{SUMMARY AND CONCLUSIONS}

The purpose of this study was to examine the recreation fee program and respondents' willingness to pay as a predictor of viability for three types of recreational passes. Given the task of maintaining public access and generating revenue, research on recreationists' willingness to pay can be an important source of knowledge for resource managers. Even prior to the implementation of the recreation fee program, the idea of a price for public leisure services had been a concept of distant concern. The recreation fee program demonstrated how resource managers were inexperienced in establishing a price for leisure services (Kyle et al., 2002). This study can assist resource managers in understanding respondents' willingness to pay for their recreational experience. This study can also help managers in implementing an effective fee price for their recreational area. This chapter reviews and discusses seven research questions. At the end of this chapter, recommendations for further research are also discussed.

\section{Summary of Procedures}

This study was derived from a secondary analysis of data. A telephonic survey was utilized to gather information from residents within three western states, including Washington, Oregon, and the Denver, Colorado metropolitan area. Interviewers from University of Florida's Survey Research Center initially conducted the survey interviews, which took place during the time period of December, 2003 through February, 2004. The telephone survey sampling was conducted through a Random-Digit Dial (RDD) process that yielded 867 completed interviews. The data analyzed for this thesis were only from respondents who were identified as Forest Service recreationists, which yielded 584 
responses. The random telephone survey to households eliminates a major flaw within the research of recreation fee studies. On-site surveys explicitly exclude those people who do not participate in outdoor recreation at certain sites due to fees or for any other reasons. The use of a telephone survey allowed for an understanding of people who have visited the National Forests in the past, while not requiring them to be recreating at the time they were interviewed.

This thesis examined seven proposed research questions. Those research questions explored willingness to pay levels by respondents for three types of recreational passes and specifically, within the National Forests of Washington, Oregon, and around the Denver, Colorado metropolitan area. The data for this thesis was analyzed via SPSS v. 11.5, which allows data entry, statistical analysis, and reporting in order to discover the results of the seven proposed research questions.

\section{Discussion of Research Questions}

\section{$R_{1}$ What is the socio-demographic makeup of the sample of respondents?}

The profiles of recreationists were examined by running the frequencies through SPSS v. 11.5. Recreationists were defined within this study of those who answered yes to the following question, "Have you participated in any outdoor recreation activities during the past 12 months?" The majority (67.4\%) of the respondents from the original sample indicated a "yes" to this question.

For the socio-demographic variable of gender, a majority of the respondents were male $(62.7 \%)$, while $37.3 \%$ were female. Slightly over one-quarter $(26.8 \%)$ of the respondents fell into the age category of 41 to 50 , while another $22.3 \%$ of respondents 
were in the age category of 51 to 60 . The remaining three age group categories were dispersed relatively equally, with $17.6 \%$ were 30 years or younger, $19.4 \%$ were 31 to 40 , and $13.8 \%$ were 61 years of age or older. A majority of the respondents were Caucasian $(87.3 \%)$, which is a lower proportion of Caucasian respondents than is typically seen at USFS sites. Typically, Caucasian respondents make-up about $92-97 \%$ of those surveyed at western U.S. National Forests (USDA Forest Service, 2005).

The respondents were also asked to report their level of education. The analysis showed that over a quarter of the respondents $(27.5 \%)$ reported acquiring their bachelor's degree. One-fifth of the respondents $(20.3 \%)$ had completed a professional or graduate degree, while the same proportion (20.3\%) reported taking college level courses but never finished their degree. Respondents' level of income was the next sociodemographic variable item. A majority of respondents (58.6\%) were employed full time, while earning an annual income ranging between $\$ 30,001$ to $\$ 50,000$. Just over one-fifth (21.4\%) of the respondents indicated an income ranging between $\$ 50,001$ to $\$ 70,000$. Respondents were also asked to indicate their permanent resident type (urban, suburban, or rural). Nearly half of the respondents $(46.2 \%)$ resided in the suburbs, with the remaining respondents living in urban (29.5\%) and rural areas (24.3\%).

Overall, respondents labeled as "recreationists" within this sample showed the typical socio-demographic profile of recreationists. Pertaining to the first research question, the greatest proportion of respondents were Caucasian males, between the ages of 41 to 60, college educated, earned an annual household salary (before taxes) ranging between $\$ 30,001$ to $\$ 70,000$, and resided in a suburban area. As noted above, the ethnicity of respondents within this study was more heterogeneous in racial/ethnic make- 
up than is normally seen of national forest respondents. This finding may differ from NVUM studies, since this research was conducted through a telephonic survey and not on-site.

\section{$\mathbf{R}_{2}$ : What is the maximum amount individuals are willing to pay for a recreational pass?}

In order to understand the maximum amount respondents were willing to pay for a Northwest Forest Pass, descriptive frequency statistics were employed. The greatest proportion of respondents (33.9\%) was willing to pay between $\$ 20$ through $\$ 30$ (mean = \$32.60) for the Northwest Forest Pass. Just over one-fifth of the respondents (20.9\%) were willing to pay a maximum amount between $\$ 50$ through $\$ 65$ for a Northwest Forest Pass. Within this study, most respondents indicated a willingness to pay slightly more (\$2.60) to purchase the Northwest Forest Pass than the current annual fee price of $\$ 30$. Respondents were also asked to report the maximum amount they would be willing to pay for a daily pass. Nearly half of the respondents (41.4\%) reported a willingness to pay between $\$ 4$ through $\$ 7$, while over one-quarter of the respondents $(28.4 \%)$ indicated between $\$ 8$ through $\$ 12$. The mean for the daily pass $(\$ 17.80)$ within this study was significantly larger than the median (\$5.00) due to data being skewed toward the maximum amount willing to pay for this pass. This resulted from a few respondents who indicated a willingness to pay between $\$ 200$ - $\$ 300$ for a daily pass. According to the median from this pass, respondents indicated a willingness to pay level that is consistent with federal land management agencies daily charge of around $\$ 5$ per person.

The last variable focused on the maximum amount respondents were willing to pay for a Golden Eagle Pass. Over one-third of the respondents (36.0\%) indicated a 
willingness to pay between $\$ 30$ through $\$ 50$ for this pass. A similar proportion of respondents (30.2\%) reported a willingness to pay between $\$ 55$ through $\$ 75$ for this annual pass $($ mean $=\$ 57.00)$.

Overall, respondents from this study indicated a willingness to pay for the Northwest Forest Pass around its current annual fee of $\$ 30$. Conversely, the daily pass revealed differences in willingness to pay between the mean and median. This significance is related to not only data being skewed toward higher price levels, but most likely other determinant factors as well. These other factors may include frequency in recreational use by respondents; and those traveling greater distances for their recreational day-use experience. Visitors traveling greater distances for their recreational experience typically show a higher value in their recreation experience and willingness to pay (McCarville, Reiling \& White, 1996). Regarding the Golden Eagle Pass, respondents indicated a willingness to pay of $\$ 57.00$, which is significantly less than the current annual fee of $\$ 65$. This significance may be related to the notion that respondents are not as familiar with this pass as compared to a Northwest Forest Pass or Daily Pass. In addition, according to the Department of Interior, the price for the Golden Eagle Pass was raised from $\$ 50$ to $\$ 65$ in April of 2000, which may also help to explain respondent's lower willingness to pay level for this pass.

\section{$\mathbf{R}_{3:}$ What is the appropriate price individuals are willing to pay for a recreational pass?}

In order to determine the appropriate price respondents were willing to pay for three types of recreational passes, descriptive statistics were analyzed for each item, along with valid percents. Regarding the Northwest Forest Pass, nearly half of the respondents $(42.0 \%)$ were willing to pay an appropriate price between $\$ 20$ through $\$ 35$ 
$($ mean $=\$ 29.85)$. Still another $29 \%$ of the respondents reported that the appropriate price was between $\$ 40$ through $\$ 55$ for this pass. The U. S. Forest Service currently charges an annual fee of $\$ 30$ for the Northwest Forest Pass, which is an appropriate price according to the mean price $(\$ 29.85)$ reported in this study.

The next variable pertained to respondents' perceptions of an appropriate price to pay for a daily pass. Nearly half (44.4\%) of the respondents indicated an appropriate price between $\$ 4$ through $\$ 7$ for this pass. Over one-third of respondents (39.7\%) reported an appropriate price between $\$ 0$ through $\$ 3$. The appropriate mean price for this pass was $\$ 8.27$, however, the median of appropriate price was in accordance with the maximum amount willing to pay of $\$ 5$.

The final appropriate price question pertained to respondents' willingness to pay for a Golden Eagle Pass. Nearly one-third of respondents (32.4\%) indicated an appropriate price between $\$ 45$ through $\$ 60$ (mean $=\$ 51.90)$. Slightly over one-quarter of the respondents $(27.4 \%)$ indicated an appropriate price between $\$ 63$ through $\$ 80$. The Department of Interior and the Department of Agriculture currently charge an annual fee of $\$ 65$ for the Golden Eagle Pass. The results from this study found an appropriate mean price of $\$ 51.90$ for the Golden Eagle Pass, which is significantly lower than the current fee price of $\$ 65$.

Overall, the current fee of $\$ 30$ for a Northwest Forest Pass appears to be an appropriate price, according to the findings from this study. Respondents also indicated an appropriate price and maximum amount for the Daily Pass between $\$ 4$ through $\$ 7$, which signifies no difference in willingness to pay levels for this pass. With regards to the Golden Eagle Pass, the Department of Interior and the Department of Agriculture, 
currently charge an annual fee of $\$ 65$ for the Golden Eagle Pass. The results from this study concluded an appropriate mean price of $\$ 51.90$ for the Golden Eagle Pass, which is significantly lower than the current fee price of $\$ 65$. As mentioned earlier, this finding could result from the fact the Golden Eagle pass is not as frequently purchased as compared to the other passes within this study. According to the Region 6 Recreation Fee Program Accomplishment Report (2004), the Golden Passports (including Golden Eagle, Age, and Access) only generated \$396,175 in revenue, while the Northwest Forest Pass was substantially greater with $\$ 3,406,382$ in total revenue. Comparing the two revenue totals for 2004, it is apparent that the Northwest Forest Pass is much more frequently bought and used among visitors of Northwest than the Golden Passports, which includes the Golden Eagle Pass.

\section{$\mathbf{R}_{4 \text { : }}$ Do perceptions of the recreation fee program predict recreationists' maximum amount willing to pay for a recreational pass?}

A series of multiple regression analyses were employed to determine the strength and significance of relationships between five fee variables and three types of recreational passes. The three dependent recreational passes included the Northwest Forest Pass, Daily Pass, and the Golden Eagle Pass. SPSS (version 11.5) was utilized to develop an index of the five-recreation fee items, which included equity of fees, social trust in the Forest Service, acceptance of fees (general and program specific), personal impact of fees, and taxes and fees. In order to determine the relationship between the independent and dependent variables, a total of three regression models (maximum amount willing to pay for each pass) were analyzed. 
The Northwest Forest Pass was the first dependent variable to be analyzed against the recreation fee variables. The analysis revealed two out of the five fee variables as being significant predictors in willingness to pay the maximum amount for a Northwest Forest Pass. These two predictors included "fee acceptance" followed by "taxes and fees." Overall, this regression model accounted for about $39 \%$ of the variance in the maximum amount willing to pay for a Northwest Forest Pass. The next regression model tested the recreation fee variables as predictors for the maximum amount willing to pay for a Daily Pass. The test results revealed no significant predictors within this regression model.

The third regression model examined the fee index and the maximum amount willing to pay for a Golden Eagle Pass. A total of two out of the five fee variables were found to be significant in willingness to pay the maximum amount for this pass. The two predictors included fee acceptance and the personal impact of fees. This model accounted for about $12 \%$ of the variance in the maximum amount willing to pay for a Golden Eagle Pass.

Overall, in reference to research question four, there were five-recreation fee variables hypothesized as predictors in willingness to pay the maximum amount. Only three out of the five recreation fee variables proved to be significant predictors of willingness to pay the maximum amount for two recreational passes. Fee acceptance proved to be the strongest predictor variable in willingness to pay the maximum amount for a Northwest Forest Pass and Golden Eagle Pass. Taxes and fees was the next strongest predictor for the Northwest Forest Pass, followed by personal impact of fees predictor for a Golden Eagle Pass. Fee equity and social trust in the Forest Service did 
not prove to be significant predictors of willingness to pay the maximum amount for the Northwest Forest Pass and Golden Eagle Pass.

\section{$\mathbf{R}_{5:}$ Do perceptions of the recreation fee program predict recreationists' appropriate price willing to pay for a recreational pass?}

Multiple regression analyses were utilized to determine the strength and

significance of relationships between fee variables and three types of recreational passes.

The three recreational passes included the Northwest Forest Pass, Daily Pass, and Golden Eagle Pass. SPSS (version 11.5) was used to develop an index of five-recreation fee variables. These fee variables included equity of fees, social trust in the Forest Service, acceptance of fees (general and program specific), personal impact of fees, and taxes and fees. In order to determine the relationship between the independent and dependent variables, a total of three regression models (appropriate price willing to pay for each pass) were conducted and analyzed.

The Northwest Forest Pass was the first dependent variable to be examined with the regression model. Three out of the five-recreation fee variables were found to be significant predictors of willingness to pay an appropriate price for a Northwest Forest Pass. The three predictors included fee acceptance, social trust within the Forest Service, and taxes and fees. Fee acceptance resulted in the strongest predictor in willingness to pay an appropriate price for this pass. This model accounted for about $38 \%$ of the variance in willingness to pay an appropriate for a Northwest Forest Pass. The next regression model tested five recreation fee predictors against the willingness to pay an appropriate price for a Daily Pass. The test results within this study revealed no significant predictors within the regression model. 
The final regression model examined the recreation fee variables against the willingness to pay an appropriate price for a Golden Eagle Pass. The regression model revealed two predictors as being significant, which included fee acceptance and taxes and fees. Fee acceptance proved to be the strongest predictor in willingness to pay an appropriate price for this pass. This model accounted for about $21 \%$ of the variance in the willingness to pay an appropriate price for a Golden Eagle Pass.

Overall, in reference to research question five, there were five recreation fee variables hypothesized. These variables were hypothesized as predictors in willingness to pay an appropriate price for three different recreational passes. Only three out of the five recreation fee variables proved to significant predictors within this study. Fee acceptance proved to be the strongest predictor in willingness to pay an appropriate price for a Northwest Forest Pass and Golden Eagle Pass. Fee equity and personal impact of fees were not significant predictors in willingness to pay an appropriate price for the Northwest Forest Pass and a Golden Eagle Pass.

\section{$\mathbf{R}_{6}$ : Are there differences in the willingness to pay model for various visitor segments based on gender, age, residence, education, and income?}

The five socio-demographic variables examined within this study were gender, age, residence type, level of education, and income. Willingness to pay for three different recreational pass variables by gender was analyzed by an independent sample t-test. This t-test was utilized to determine if any significant differences existed between male and female respondents in their willingness to pay levels. The t-test results revealed a significant difference between males and females regarding their willingness to pay an appropriate price for a Northwest Forest Pass. Females were willing to pay (\$34.56) more for a Northwest Forest Pass than males (\$27.27). Females might perceive more value in 
paying an appropriate price for a Northwest Forest Pass than males. According to an examination of the recreation fee program of the Northwest in 2002, females were more supportive of the fee program, and also reported higher satisfaction scores than males; which can lead to a higher willingness to pay level (Burns, Graefe \& Robinson, 2002).

The remaining four socio-demographic variables (age, residence, education, and income) were examined using a one-way analysis of variance (ANOVA) for each variable. The ANOVA test results revealed residence type and education as having significant differences between groups. Age and income proved to be insignificant variables within this study. The ANOVA test results for residency type revealed a significant difference in an appropriate price to charge for a Golden Eagle Pass. Suburban residence $($ mean $=57.15)$ reported the highest mean for an appropriate price; followed by urban $($ mean $=49.68)$, and rural $($ mean $=44.29)$. Suburban residents were willing to pay a higher appropriate price than urban and rural residents.

The ANOVA results for education level, revealed a significant difference in the maximum amount willing to pay for a Golden Eagle Pass. Those with a graduate degree or higher $(\mathrm{F}=65.43)$ reported the highest mean score in willingness to pay the maximum amount for this pass; followed by an associate's or bachelor's degree $(\mathrm{F}=57.51)$, and than those with an associates degree $(\mathrm{F}=51.82)$. This finding shows that as respondents who were more educated, were willing to pay a higher price for a Golden Eagle Pass.

Overall, the research findings reveal that residence type and level of education seem to play an important role in determining willingness to pay an appropriate and maximum amount for a Golden Eagle Pass. 


\section{$\mathbf{R}_{7}$ : What is the proper balance between fees and taxes?}

To determine the proper balance between fees and taxes, a one-way analysis of variance was utilized. An ANOVA was used to determine if any significant differences existed in willingness to pay for three recreational passes against user fees and taxes. The findings revealed five out of the six variables as being significant predictors. The highest means were noted for the item "our national forests should be funded equally from taxes and fees" category. This finding was most important for the willingness to pay the maximum amount for a Golden Eagle Pass; followed by willingness to pay the maximum and appropriate amount for a Northwest Forest pass.

Overall, the findings revealed that most respondents were willing to pay for their recreational experience when it was equally funded from taxes and fees.

\section{Discussion}

The purpose of this study was to examine the recreation fee program and willingness to pay. Implemented under the Clinton administration, the recreation fee demonstration program was initially approved in 1996 as a three-year pilot program. The fee program was authorized to explore the feasibility of utilizing recreation fees on public lands. It was believed that recreation fees would help generate increased revenue in order to deal with the backlog of maintenance on federal lands. An increase in revenue could also improve the quality of visitor services and enhance the protection of natural resources. The recreation fee program was extended numerous times until its permanent authorization through the Federal Lands Recreation Enhancement Act (FREA) in 2004. Over the years, the recreation fee program has sparked many public debates regarding the benefits and costs of charging recreation fees on public lands. As a result, this study 
examined respondents' willingness to pay as a predictor for three types of recreational passes.

The sample of respondents examined within this study was fairly representative of visitors who typically recreate on the National Forests of the Pacific Northwest and Colorado. The ratio of males to females was about 60 to 40 , with the main age group being between 41 to 60 years of age. Nearly half of the respondents resided in a suburban area, while earning an income range from $\$ 30,001$ to $\$ 70,000$. The proportion of nonCaucasian respondents was higher than that seen in typical on-site surveys.

The hypothesized relationship between the socio-demographic variables (gender, age, residence, income, and education) revealed significant differences in regards to willingness to pay. The significant differences found in willingness to pay for a recreation pass included gender, residence, and education. With regards to gender, males were more likely to report a lower appropriate price for a Northwest Forest Pass than females. This significance can illustrate that females, or in this case females, who accept the notion of recreation fees are more willing to perceive certain recreation fees as fairly priced.

Respondents who lived in a suburban residence area were significantly more willing to pay a higher appropriate price for a Golden Eagle pass than urban or rural residents. The level of education also proved to be a significant indicator in respondents' willingness to pay levels. Respondents with a graduate degree or higher reported the highest means in willingness to pay the maximum amount for a Golden Eagle Pass; followed by those with bachelor/associates degree. The significant relationship between willingness to pay for a Golden Eagle Pass and education signifies that the more educated respondents were, the more willing they were to pay a higher maximum amount for this pass. 
Overall, gender, education, and place of residence showed significant differences in willingness to pay for a recreational pass. Interestingly, income showed no significance in willingness to pay. With regards to gender, females might perceive more value or equity in the recreation fee program and are willing to pay a higher appropriate price than males. Within our society, more educated individuals typically make a higher salary than those with no education. Therefore, these individuals have the economic means to pay a greater amount for a recreational pass and can afford to reside within a suburban area.

Five predictors from the recreation fee program were also examined within this study. Those predictors were examined to identify differences in willingness to pay for three types of recreational passes. The results of the regression analyses showed that willingness to pay the maximum and appropriate amount varied with each type of recreational pass.

For the Northwest Forest Pass, fee acceptance and taxes and fees were significant for the maximum and appropriate amount, while social trust in the Forest Service was only significant for the appropriate amount. For the Golden Eagle Pass, fee acceptance was significant for willingness to pay the maximum and appropriate amount. Personal impact of fees was also significant for the willingness to pay the maximum amount for the Golden Eagle Pass, while only taxes and fees were significant with the appropriate amount for the Golden Eagle Pass.

The recreation fee predictors, fee acceptance and taxes and fees, proved to have a significant difference in the willingness to pay for a Northwest Forest Pass and Golden Eagle Pass. It is apparent that if an individual accepts fees, he or she would be more willing to pay for their recreational experience. However, respondents felt that fees alone 
should not be used to make up for declining agency budgets. They strongly agreed that recreation is a social good and should also be supported by tax dollars.

Social trust in the Forest Service was also found to be an important factor affecting willingness to pay an appropriate price. Trust in an agency can be based on the environmental risk management theory, which helps to explain that people accept certain actions if they trust the agency (Nyaupane, 2004; Slovic, 1997). These actions can lead to a greater acceptance of the recreation fee program, and a willingness to pay for their recreational experience.

The daily pass proved to be insignificant between the two regression models of willingness to pay the maximum and appropriate amount, which is similar to the findings of Nyaupane (2004). The determinant factor behind the daily pass's insignificance can be related to price inelasticity and acquisition utility. According to Nyaupane's study (2004), as the bid prices increased, the willingness to pay for the daily pass decreased. In other words, as the price of the fee goes up, an individual is less willing to pay the fee, and is less likely to perceive this price as fair. It is also important to consider that the daily pass is the most common pass, while the Northwest Forest Pass and Golden Eagle Pass may not be as familiar to the respondents.

This study as well as other studies, has suggested that the general public supports recreation user fees on public lands. However, according to McCarville, Reiling, \& White (1996), there is a substantial group of day-users who oppose paying for public leisure services.

Acquisition utility can be utilized to help explain this and the insignificance of the predictors regarding the daily pass within this study. Acquisition utility represents a test 
of fairness, which is applied when individuals compare the value they believe they have received against the level of their investment (Thaler, 1985). For example, proximity to a recreational site may influence assessments of acquisition utility. A travel cost analysis suggests that local users may perceive limited benefit accruing from their individual visits. Individuals residing close to a recreational day-use site may tend to make multiple but shorter-duration visits to this site, because of the minimal travel costs incurred (McCarville et al., 1996). The overall travel cost to the recreational area is substantially low compared to individuals traveling greater distances. Therefore, these individuals recreating on a site only a few miles away from their home, typically have more diverse but low valued (more price elastic) activities. These low valued activities can displace day-use visitors to areas where no recreation fee is charged. For example, most individuals would not pay $\$ 5$ a day to walk their dog at a recreation fee site. These individuals would seek other non-fee day use recreation sites to walk their dog.

Conversely, individuals traveling greater distances for their leisure experience are more willing to pay, because admission charges only consume a small portion of their total travel costs. Because of the higher travel costs, these individuals may participate in higher valued activities; and might even pursue several activities at a day-use site.

Willingness to pay for a daily pass can significantly be impacted by the distance individuals reside from the recreation site. Recreation fees tend to have a higher marginal cost for local visitors and therefore, fees tend to reduce the support most among those visitors who reside nearby. Residential proximity, like past experience to a recreation day-use site, can also indicate a difference in commitment, knowledge, and use patterns related to that recreation site (McCarville et al., 1996). For example, local visitors tend to 
have different use patterns than non-locals by making more frequent and shorter trips to the day-use site. Thus, local visitors are likely to be more knowledgeable about the area and more aware about the history of fees at the recreation site than individuals residing out of the local area. As a result, locals may have a greater tendency to form a reference price (what consumers expect to pay) based on their past experience and knowledge of the recreation site. For example, if the recreation day-use site was previously free, then implementing a fee for this site would violate the visitor's price expectations. Plus, local visitors are also likely to feel some sense of ownership or attachment to a day-use area that is relatively close to their home, and perceive fees as having a greater impact on them than non-local visitors. Therefore, since day-use fees represent a large portion of their total travel costs, local visitors are more likely to be displaced to areas where no fee is charged.

Some other factors can be related to the non-significant findings concerning the analysis of the daily pass within this study. Some of these factors include frequency of use to a recreational area and convenience in purchasing a daily pass. For example, local visitors who recreate at a day-use recreational site more frequently will be less inclined to pay a daily fee compared to non-local visitors. As a result, a daily fee will have the greatest impact on frequent visitors, and those who recreate less will often show a higher willingness to pay for a daily pass. As a result, a daily pass is economically more efficient for non-local visitors, while an annual recreational pass is more beneficial for local visitors (e.g., Northwest Forest Pass) (McCarville et al., 1996).

The convenience in purchasing a daily pass plays another important factor in willingness to pay. Displacement can occur from visitors who do not know how to pay a 
daily fee once arriving at the recreation site, or where to go to purchase the fee if it is to be purchased elsewhere. It is important for resource managers to properly display fee pass information for the publics' knowledge (e.g., kiosks).

Overall, local residents tend to be more affected by recreation fees because the frequency of their visits, bear a higher cumulative cost. In addition, local residents travel less distances to their favorite recreation sites, so any kind of fee incurred will result in a larger percent of the overall travel cost. While compared to the overall costs paid by nonlocal visitors with higher travel costs. From a philosophical perspective, local residents may express a desire for a discount or exemption from a daily fee, based upon their past experience and frequency of use at the recreation site.

\section{Management Implications}

Predicting an appropriate fee level for public leisure services is an obstacle still

faced today by resource managers. Research on recreation fees can assist managers with a better understanding to embark upon the complex issues related to fees, including willingness to pay. The findings within this study offer some insights into willingness to pay for managers of public land agencies.

A majority of respondents were willing to pay an amount in line with the current fee prices being implemented by our Federal land management agencies. Fee acceptance and using a combination of taxes and fees were found to be important predictors in willingness to pay for a recreational pass.

Overall, the daily pass illustrated very different results than the other two recreational pass variables within this study. Day-use recreation sites play a vital role in the outdoor recreation field. These sites also receive a large amount of recreational use, 
but have received little research emphasis. In the future, to gain a better understanding of day-use recreationists it is important for researchers and resource managers to focus their research efforts on this particular user group.

\section{Recommendations for Future Research}

With the permanent authorization of the recreation fee program through the

Federal Lands Recreation Enhancement Act (FREA), a priority of this act is to clarify the circumstances where a fee may be charged. Another important point of FREA is that it seeks to implement a fee program that is fair and equitable to visitors. The social environment for many outdoor recreation sites have been changing over recent years. In some areas of the country this has been in ethnic/racial populations, education, age, or even income. These changes will bring along a different set of behaviors and values that differ from the "traditional" user on public lands (Chavez, 2003). Therefore, willingness to pay research will become even more important within the future, not only from the permanent authorization of the fee program but as more minorities recreate on public lands and the wave of baby boomers begin their retirements next year. Therefore, researchers and resource managers should continue to evaluate respondents' willingness to pay levels within the future on public lands. In the future, it would also be interesting to conduct a recreation fee study that examines local versus non-local visitors in their willingness to pay for recreation experience. In addition, it would also be interesting to measure and compare the frequency of use for local vs. non-local visitors on a specific day use site within a National Forest area. This research could help explain if distance is a predictor in willingness to pay for a daily fee by visitors. Overall, more research is 
needed in the future to better understand the underlying implications of visitors willingness to pay for a daily pass. 


\section{REFERENCES}

Ajzen, I., \& Driver, B. L. (1992). Contingent value measurement: On the nature and meaning of the willingness to pay. Journal of Consumer Psychology, 1(4), 297316.

Anderson, K. H., \& Freimund W. A. (2004). Multiple dimensions of active opposition to the recreational fee demonstration program. Journal of Park and Recreation Administration, 22(2), 44-64.

Babbie, E. (1995). The practice of social science research $\left(7^{\text {th }}\right.$ ed.). New York: Wadsworth Publishing Company.

Bamford, T., Manning, R., Forcier, L., \& Koenemann, E. (1988). Differential campsite pricing: An experiment. Journal of Leisure Research 20(4),324-342.

Bates, N. A. (1999, July). Paying to play: The future of recreation fees. Parks and Recreation, 47-52.

Bengston, D.N., \& Fan, D.P. (2001). Trends and attitudes toward the recreation fee Demonstration program on the national forests: A computer content analysis approach. Journal of Park and Recreation Administration, 19(4), 1-21.

Benzar, K. (2005). Site survey and analysis of Forest Service and Bureau of Land Management: Implementation of federal lands recreation enhancement act. Retrieved November 20, 2005 from, http://www.westernslopenofee.org

Borrie, W.T., Christensen, N., Watson, A. E., Miller, T. A., \& McCollum, D.W. (2002). Public purpose recreation marketing: A focus on the relationships between the public and public lands. Journal of Park and Recreation Administration, 20(2), 49-68.

Bowker, J. M., Cordell, H. K., \& Johnson, C. Y. (1999). User fees for recreation services on public lands: A national assessment. Journal of Park and Recreation Administration, 17(3), 1-14.

Burns, R. C., \& Graefe, A. R. (2003). Pacific Northwest Region recreation fee programs. University of Florida and The Pennsylvania State University.

Burns, R. C., Graefe, A. R., \& Robinson, K. F. (2002). An examination of the Pacific Northwest Region recreation fee program. University of Florida and The Pennsylvania State University.

Burns, R. C., \& Graefe, A. R. (in press). Toward understanding recreation fees: Impacts on people with extremely low income levels. Journal of Park and Recreation Administration. 
Chavez, D. J., Olson, D. D., \& Madrid, K. (2003). Day use of national forest series: The Inyo National Forest. Unpublished report. Riverside, CA: Pacific Southwest Research Station, Forest Service, U.S. Department of Agriculture.

Crompton, J. L. (1981). How to find the price that's right. Parks \& Recreation 16(3), 3239.

Crompton, J. L., \& Kim, S. S. (2001). Reactions to a large increase in admission price to state parks. Journal of Park and Recreation Administration, 19(4), 42-59.

Dustin, D. L., More, T. A., \& McAvoy, L. H. (2000). The faithful execution of our public trust: Fully funding the National Parks through taxes. Journal of Park and Recreation Administration, 18(4), 92-103.

Farmer, S. (2004). An examination of service quality indicators as a predictor of customer satisfaction for US Forest Service recreationists. Unpublished master's thesis, University of Florida.

Fretwell, H. L. (1999). Paying to play: The fee demonstration program (Policy Series No. PS-17). Bozeman, MT: PERC.

Garber-Yonts, B. (2005). What's it worth to you? Estimating the public's willingness to pay for biodiversity conservation. Science Findings, 77, 1-5.

Helson, H. (1964). Adaptation level theory. New York: Harper \& Row.

Kahneman, D., \& Tversky, A. (1979). Prospect theory: An analysis of decision under risk. Econometria, 47(2), 263-291.

Kamen, J., \& Toman, R. (1970). Psychographics of pricing. Journal of Marketing Research, 7, 27-35.

Kim, S., \& Crompton, J. L. (2001). The effects of different types of information messages on perceptions of price and willingness to pay. Journal of Leisure Research, 33(3), 299-318.

Kyle, G. T., Graefe, A. R., \& Absher, J. D. (2002). Determining appropriate prices for recreation on public lands. Journal of Park and Recreation Administration, 20(2), 69-89.

Kyle, G. T., Absher, J. D., \& Graefe, A. R. (2003). The moderating role of place attachment on the relationship between attitudes toward fees and spending preferences. Leisure Sciences, 25, 33-50.

Loomis, J. B. \& Walsh, R. G. (1997). Recreation economics decisions. State College, PA: Venture Publishing. 
Loomis, J., Pierce, C., \& Manfredo, M. (2000). Using the demand for hunting licenses to evaluate contingent valuation estimates of willingness to pay. Applied Economics Letters, 7(7), 435-438.

McCarville, R. E. \& Crompton, J. (1987). An empirical investigation of the influence of information on reference prices for public swimming pools. Journal of Leisure Research, 19(3), 223-235.

McCarville, R. E. (1991). An empirical investigation of the influence of cost information on willingness to pay for public aerobic classes. Leisure Sciences, 13, 85-96.

McCarville, R. E. (1995). Pricing for public leisure services: An ethical dilemma? Journal of Applied Recreation Research, 20(2), 95-108.

McCarville, R. E. (1996). The importance of price last paid in developing price expectations for a public leisure service. Journal of Park and Recreation Administration, 14(4), 52-64.

McCarville R. E. (1997). The anchoring effect of price-last-paid information on willingness-to-pay levels. Journal of Applied Recreation Research, 22, 191-209

McCarville, R. E., Reiling, S. D., \& White, C. M. (1996). The role of fairness in users' assessments of first-time fees for a public recreation service. Leisure Sciences, 18, 61-76.

McClosky, D. (1982). The applied theory of price. New York: MacMillan.

Mitchell, R. C. \& Carson, R. T. (1989). Using surveys to value public goods: The contingent valuation method. Washington, DC: Resources for the Future.

More, T., Dustin, D., \& Knopf, R. (1996). Behavioral consequences of campground user fees. Journal of Park and Administration, 14(1), 81-93.

More, T. A. (1998). User fees and public objectives in recreation management. Trends, 35(2), 23-26.

More, T.A. (1999). A functionalists approach to user fees. Journal of Leisure Research, 31(3), 227-244.

More, T. \& Stevens, T. (2000). Do user fees exclude low-income people from resource based recreation? Journal of Leisure Research, 32(9), 341-357.

More, T. A. (2002). "The parks are being loved to death" and other frauds and deceits in recreation management. Journal of Leisure Research, 34(1), 52-78. 
Nyaupane, G. P. (2004). Determining the role of equity in recreation fee acceptance and fair price on federally managed public lands. Unpublished doctoral dissertation, The Pennsylvania State University.

Ostergren, D., Solop, F. I., \& Hagen, K. K. (2005). National park service fees: Value for the money or a barrier to visitation? Journal of Park and Recreation Administration, 23(1), 18-36.

Reiling, S. D., \& Anderson, D. M. (1985). Equity and efficiency in the public provision of forest-based recreation opportunities. Journal of Environmental Management, 20, 149-161.

Reiling, S., Cheng, H., \& Trott, C. (1992). Measuring the discriminatory impact associated with higher recreation fees. Leisure Sciences, 14, 121-137.

Reiling, S. D, McCarville, R. E., \& White, C. M. (1994). Demand and marketing study at army corps of engineers day-use areas. Vicksburg, MS: Waterways Experiment Station.

Richer, J. R. \& Christensen, N. A. (1999). Appropriate fees for wilderness day use: Pricing decisions for recreation on public land. Journal of Leisure Research, 31(3), 269-280.

Rosenthal, D. H., Loomis, J. B., \& Peterson, G. L. (1984). Pricing for efficiency and revenue in public recreation areas. Journal of Leisure Research, 16(3), 195-208.

Schneider, I. E. \& Budruk, M. (1999). Displacement as a response to the federal recreation fee program. Journal of Park and Recreation Administration, 17(3), 76-84.

Schroeder, H. W. \& Louviere, J. (1999). Stated choice models for predicting the impact of user fees at public recreation sites. Journal of Leisure Research, 31(3), 300324.

Rey, M. (2005). Implementation of the recreation enhancement act. Retrieved November 10, 2005, from http://energy.senate.gov/public

Stone, T. (1996). Recreational fee collection in the National Park Service. Recreation fees in the National Park Service: Issues, policies, and guidelines for future action, ed. A. L. Lundgren. Minnesota Extension Service Pub. no. BU-6767 St. Paul, MN: Cooperative Park Studies Unit, Department of Forest Resources, University of Minnesota.

Thaler, R. (1985). Mental accounting and consumer choice. Marketing Choice, 4(3), 199214. 
Trainor, S. F. \& Norgaard, R. B. (1999). Recreation fees in the context of wilderness values. Journal of Park and Recreation Administration, 17(3), 100-115.

U.S.D.A. Forest Service: Recreation fee program 2004 accomplishment report: Recreation fees fund your priorities. Retrieved March 13, 2006 from http://www.fs.fed.us/r6/feedemo/docs/04-accomp-rpts/04-r6-accomplishmentreport.pdf

U.S.D.A Forest Service: National forest visitor use monitoring program-national project results-January 2000 through September 2003. Retrieved April 4, 2006 from http://www.fs.fed.us/recreation/programs/nvum

U.S.D.A Forest Service: National forest maps of Colorado. Retrieved December 3, 2005, from http://www.fs.fed.us/r2/recreation/map/index.html

U.S.D.A Forest Service: National forest maps of Oregon and Washington. Retrieved December 3, 2005, from http://www.fs.fed.us/r6/r6nf.htm

U.S. Department of Interior: Recreation fee program. (n.d.) Retrieved January 12, 2006, from http://www.doi.gov/initiatives/recreation_feeprogram.html

U.S. Department of Interior: Golden eagle passport to cost more, new park entry pass planned. (April 4, 2000) Retrieved April 25, 2006 from http://www.doi.gov/news/archives/000404.html

US General Accounting Office (1998). Recreation fees: Demonstration fee program successful but could be improved (GAO/RCED-99-7). Washington, DC: General Accounting Office.

US General Accounting Office (2003). Recreation fee demonstration program: Progress report to Congress, Fiscal Year 2002: U.S. Department of Interior and U.S. Department of Agriculture.

US General Accounting Office (2004). Recreation fee demonstration program: Progress report to Congress, Fiscal Year 2003: U.S. Department of Interior and U.S. Department of Agriculture.

Vaske, J. J., Donnelly, M. P., \& Tayler J. G. (1999). The price is about right: National wildlife refuge visitors' evaluations of the fee demonstration program. Human Dimensions of Wildlife, 4(4), 62-72.

Warren, R. \& Rea, P. (1998). Fee-supported parks: Promoting success. Parks and Recreation, 33(1), 82-88.

Watson, A. E. \& Herath, G. (199). Research implications of the theme issues "recreation Fee and pricing issues in the public sector" (Journal of Park and Recreation 
Administration) and "societal response to recreation fees on public lands" (Journal of Leisure Research). Journal of Leisure Research, 31(3), 325-334.

Williams, D. R., Vogt, C. A., \& Vitterso, J. (1999). Structural equation modeling of users' response to wilderness recreation fees. Journal of Leisure Research, 31(3), 245-268.

Williams, D. R., \& Watson, A. E. (1998). The impact of place meaning and place attachment on attitudes towards fees for wilderness use. In proceedings, Seventh International Symposium on Society and Resource Management. Columbian, MO: University of Missouri-Columbia. 
APPENDIX

QUESTIONAIRE

TELEPHONE INTERVIEW 
Introduction.

First I would like to ask you some questions about outdoor recreation activities. By outdoor recreation, we mean land, water, and snow-based activities.

1. How interested are you in outdoor recreation activities? Are you very interested, somewhat interested, or not at all interested in outdoor recreation activities?

1. Very Interested

2. Somewhat Interested

3. Not at all Interested

4. Don't Know

5. Refused

2. What kinds of outdoor recreation activities do you like to do?

[INTERVIEWER: Open-ended, record response verbatim]

3. A lot of outdoor recreation opportunities in Oregon and Washington are on lands managed by the Forest Service and are called National Forests. National Forests are different from State Parks and National Parks.

What do you think of when you hear the words "National Forest?" Please tell me the first few characteristics, images or things that come to mind. [INTERVIEWER: Open-ended, record response verbatim]

4. Have you ever visited a National Forest in Oregon or Washington?

1. Yes (If yes-Forest Service recreationist, go to Q5)

2. No (If no-other recreationist, go to Q7)

3. I don't know (If don't know-other recreationist, go to $Q 7$ )

FS RECREATIONISTS

During the last twelve months, how many trips have you made to any

National Forest in Oregon or Washington?

What is your primary National Forest in Oregon or Washington - the one that you visit most often?

6a. Do you have a favorite place or area within the National Forest that you return to on a regular basis?

No___ Yes [If yes] Where is that? (name of place)

How far is that place from your residence

Why do you go there?

What makes this place special to you?

ALL 
7. During the last twelve months, how many recreation trips have you made to non-

National Forest lands (e.g. National Parks, State Parks, private lands, etc.) in Oregon

or Washington?

8. What types of areas do you visit for outdoor recreation?

\begin{tabular}{|l|l|l|}
\hline & $\checkmark$ for each area selected & $\begin{array}{c}\text { \# of trips in last 12 months } \\
\text { (for each type selected) }\end{array}$ \\
\hline National Parks & & \\
\hline State Parks & & \\
\hline National Wildlife Refuges & & \\
\hline Bureau of Land Management Areas & & \\
\hline Other (specify & & \\
\hline
\end{tabular}

Non-FS RECREATIONISTS (if answer 2 or 3 to question 4 or answer 0 to question 5)

1. I'd like to read some reasons why people do not visit forests, or don't visit them very often. For each one, please tell me if it is a major reason why you haven't visited a National Forest in the last year, a minor reason, or not a reason for you. The first one is... [Read each item, randomize list and rotate start]

Would you say this is a major reason, a minor reason, or not a reason why you haven't visited a National Forest this past year?

\begin{tabular}{|l|c|c|c|c|}
\hline \multicolumn{1}{|c|}{ Reason } & $\begin{array}{l}\text { Major } \\
\text { Reason }\end{array}$ & Minor Reason & Not a Reason & Not Sure \\
\hline Fear of the outdoors & 1 & 2 & 3 & 4 \\
\hline Don't have enough time & 1 & 2 & 3 & 4 \\
\hline Have no way to get to the forests & 1 & 2 & 3 & 4 \\
\hline $\begin{array}{l}\text { Lack of information about the forests or things to do } \\
\text { there }\end{array}$ & 1 & 2 & 3 & 4 \\
\hline Fear of crime & 1 & 2 & 3 & 4 \\
\hline Too busy with other activities & 1 & 2 & 3 & 4 \\
\hline Poor health & 1 & 2 & 3 & 4 \\
\hline Don't have anyone to go with & 1 & 2 & 3 & 4 \\
\hline National Forests are too far away & 1 & 2 & 3 & 4 \\
\hline National Forests are too crowded & 1 & 2 & 3 & 4 \\
\hline Like to do other things for recreation & 1 & 2 & 3 & 4 \\
\hline Don't like to do things outdoors & 1 & 2 & 3 & 4 \\
\hline $\begin{array}{l}\text { I, or someone I travel with, is physically unable to } \\
\text { visit National Forests }\end{array}$ & 1 & 2 & 3 & 4 \\
\hline $\begin{array}{l}\text { National Forests have too many rules that I don't } \\
\text { like }\end{array}$ & 1 & 2 & 3 & 4 \\
\hline Don't like the facilities in National Forests & 1 & 2 & 3 & 4 \\
\hline Can't afford to go to the National Forests & 1 & 2 & 3 & 4 \\
\hline Areas are closed when I want to visit & 1 & 2 & 3 & 4 \\
\hline $\begin{array}{l}\text { Are there any other reasons you haven't visited a } \\
\text { National Forest this past year [If any, record } \\
\text { response verbatim] }\end{array}$ & & & & \\
\hline
\end{tabular}

2. What could the Forest Service do that would make you more likely to visit the National Forests?

\section{FS RECREATIONISTS}


1. Do you visit the National Forests in your area as often as you would like to?

1. Yes [If yes, skip question 2 and continue]

2. No [If no, ask question 2 and continue]

2. I'd like to read some reasons why people do not visit forests, or don't visit them very often. For each one, please tell me if it is a major reason why you haven't visited National Forests as often as you would like to, a minor reason, or not a reason for you. The first one is... [Read each item, randomize list and rotate start]

Would you say this is a major reason, a minor reason, or not a reason why you do not visit National Forests as often as you would like to?

\begin{tabular}{|c|c|c|c|c|}
\hline Reason & $\begin{array}{l}\text { Major } \\
\text { Reason }\end{array}$ & Minor Reason & Not a Reason & Not Sure \\
\hline \multicolumn{5}{|l|}{ Fear of the outdoors } \\
\hline Don't have enough time & 1 & 2 & 3 & 4 \\
\hline Have no way to get to the forests & 1 & 2 & 3 & 4 \\
\hline $\begin{array}{l}\text { Lack of information about the forests or things to do } \\
\text { there }\end{array}$ & 1 & 2 & 3 & 4 \\
\hline Fear of crime & 1 & 2 & 3 & 4 \\
\hline Too busy with other activities & 1 & 2 & 3 & 4 \\
\hline Poor health & 1 & 2 & 3 & 4 \\
\hline Don't have anyone to go with & 1 & 2 & 3 & 4 \\
\hline National Forests are too far away & 1 & 2 & 3 & 4 \\
\hline National Forests are too crowded & 1 & 2 & 3 & 4 \\
\hline Like to do other things for recreation & 1 & 2 & 3 & 4 \\
\hline Don't like to do things outdoors & 1 & 2 & 3 & 4 \\
\hline $\begin{array}{l}\text { I, or someone I travel with, is physically unable to } \\
\text { visit National Forests }\end{array}$ & 1 & 2 & 3 & 4 \\
\hline $\begin{array}{l}\text { National Forests have too many rules that I don't } \\
\text { like }\end{array}$ & 1 & 2 & 3 & 4 \\
\hline Don't like the facilities in National Forests & 1 & 2 & 3 & 4 \\
\hline Can't afford to go to the National Forests & 1 & 2 & 3 & 4 \\
\hline Areas are closed when I want to visit & 1 & 2 & 3 & 4 \\
\hline $\begin{array}{l}\text { Are there any other reasons you haven't visited a } \\
\text { National Forest as often as you would like to [If } \\
\text { any, record response verbatim] }\end{array}$ & & & & \\
\hline
\end{tabular}

3. What could the Forest Service do that would make you more likely to visit the National Forests? 
4. Here is a list of some benefits people have told us they seek through outdoor recreation. Please tell me how important each of the following benefits is to you when you visit your primary National Forest in Oregon or Washington. [One is not at all important and five is extremely important] ... [Read each item, randomize list and rotate start]

\begin{tabular}{|c|c|c|c|c|c|}
\hline & 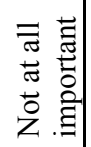 & 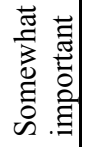 & 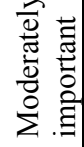 & 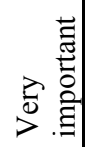 & 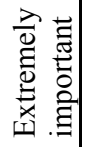 \\
\hline Improved physical health & 1 & 2 & 3 & 4 & 5 \\
\hline Strengthened relationships with my companions & 1 & 2 & 3 & 4 & 5 \\
\hline Increased self-confidence & 1 & 2 & 3 & 4 & 5 \\
\hline Reduced stress & 1 & 2 & 3 & 4 & 5 \\
\hline Enhanced family relationships & 1 & 2 & 3 & 4 & 5 \\
\hline Improved mental health & 1 & 2 & 3 & 4 & 5 \\
\hline Spiritual growth & 1 & 2 & 3 & 4 & 5 \\
\hline Increased appreciation of the area's cultural history & 1 & 2 & 3 & 4 & 5 \\
\hline Greater connection with nature & 1 & 2 & 3 & 4 & 5 \\
\hline Provides opportunity for solitude & 1 & 2 & 3 & 4 & 5 \\
\hline Provides a challenge that tests my abilities & 1 & 2 & 3 & 4 & 5 \\
\hline Provides a sense of adventure & 1 & 2 & 3 & 4 & 5 \\
\hline Provides opportunities to meet people & 1 & 2 & 3 & 4 & 5 \\
\hline Greater connection with wilderness & 1 & 2 & 3 & 4 & 5 \\
\hline Increased sense of competence & 1 & 2 & 3 & 4 & 5 \\
\hline Provides opportunities to view wildlife & 1 & 2 & 3 & 4 & 5 \\
\hline Opportunity for lifelong learning & 1 & 2 & 3 & 4 & 5 \\
\hline
\end{tabular}


6. The Forest Service started charging fees at many places on the National Forests in Oregon and Washington in the last couple of years. Have you heard of the Northwest Forest Pass?

No

[If no, follow questions in column below]

The Northwest Forest Pass costs $\$ 30$ annually. This pass allows you to enter many National Forest fee areas in Oregon and Washington. Knowing this information, would you now be interested in purchasing such a pass?

1 Yes

2 No
Yes

[If yes, follow questions in column below]

Where did you find out about the Northwest Forest Pass?

How would you rate your support for the Northwest Forest Pass?

1 Strongly support

2 Support

3 Neutral

4 Oppose

5 Strongly oppose

Please tell us how your opinion of the Northwest Forest Pass has changed since your first heard of the program.

1 Much more support

2 More support

3 No change

4 More opposition

5 Much more opposition

7. Do you personally have any of the following types of recreation passes? (Check all that apply)

Golden Eagle

Golden Age

Golden Access

National Parks Pass

National Parks Pass w/ Golden

Eagle Hologram
Northwest Forest Pass

Other local/regional annual pass

State of Oregon Pass

State of Washington Pass

NONE

\section{$\sim \sim \sim \sim \sim \sim \sim R E C R E A T I O N$ PASS HOLDERS ONLY (answer yes to any of above types of}

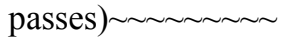

8. How did you learn about the recreation pass that you purchased?

9. Where did you purchase the pass? (check one)

Order by mail from Forest Service Buy the pass over the internet Call a 1-800 number

Purchase at a Forest Service office Purchase at the recreation site
Buy the pass at a convenience store Buy the pass at an outdoor shop Buy the pass at a "sno-park" vendor Buy the pass at a grocery store Buy the pass at a fishing or hunting license vendor Other (specify

10. Why did you purchase the pass? 
11. Where do you use your recreation pass most often? (check one)

National Forest, National Park, National Wildlife Refuges, BLM, State

Park, Other (specify )

12. In what year did you first purchase this type of annual pass?

13. How often do you use your recreation pass each year? number of times in past 12 months number of different areas visited in past 12 months

14. What was the most important reason for obtaining your recreation pass this year?

(Reason)

15. How has purchasing the pass affected your outdoor recreation participation? increased my participation, decreased my participation, has NOT changed my

participation

16. What do you like most about the pass?

16a. If yes, which type of pass and when did you purchase it? (type) (year)

$16 \mathrm{~b}$. Why didn't you purchase the pass this year?

17. How could it be improved?

18. (If respondent has one or more federal pass)

Federal and state land agencies are considering developing one recreation pass that would be accepted at all federal recreation sites and most state recreation sites across the US (for example, state parks). You would be able to purchase a decal to upgrade your federal pass for each state. Would you consider purchasing a decal to upgrade your federal pass to include state recreation sites at a cost of between $\$ 20-\$ 50$ per state?

I would definitely purchase multiple state decals I would definitely purchase at least one state decal I might purchase at least one state decal I probably would not purchase any state decals I definitely would not purchase any state decals Don't know 
19. Have you ever purchased any of these types of passes in the past?

Yes No

20. Are you aware that annual recreation passes are available for purchasing at many locations across Oregon \& Washington? Yes No when

If yes, where and when did you learn about the pass? where

21. Please tell me the main reason why you have not purchased an annual recreation pass:

22. What would make you more likely to purchase an annual recreation pass?

23. Where would you seek information about the recreation passes that are offered? (Check all that apply)

Outdoor/Sporting Goods Stores

Newspapers

Books \& Magazines

Brochures

Trailhead Signs
Ranger or Volunteer

Visitor Center/Ranger Station

The Internet

Television

Recreation clubs or organizations 
ALL

24. We are interested in learning about how often you participate in various outdoor activities, and how you feel about paying for them. Please consider your participation in the following activities, regardless of where you have participated (e.g. not just activities you have done in National Forests). For each activity mentioned, I will ask you three things:

FIRST, how many times have you participated in the activity at any location during the past 12 months;

SECOND, whether or not you have ever paid a fee to participate in that activity;

THIRD, how acceptable paying the fee was to you (if you have paid) or how acceptable paying a fee would be to you (if you have never paid for that activity). For this last rating, please use the following scale and select the number that best describes your feeling for each activity in the space provided.

\begin{tabular}{ccccc}
-2 & -1 & 0 & +1 & +2 \\
\hline Completely & Somewhat & Neutral & Somewhat & Completely \\
Unacceptable & Unacceptable & & Acceptable & Acceptable
\end{tabular}

\begin{tabular}{|c|c|c|c|c|c|c|c|c|}
\hline \multirow[b]{2}{*}{ Wilderness or backcountry camping } & \multirow[t]{2}{*}{$\begin{array}{l}\text { Number of times } \\
\text { in past } 12 \text { months }\end{array}$} & \multicolumn{2}{|c|}{$\begin{array}{c}\text { Have you paid a fee to } \\
\text { participate in this activity }\end{array}$} & \multicolumn{5}{|c|}{$\begin{array}{l}\text { Acceptability of fee } \\
\text { (scale of }-2 \text { to }+2)\end{array}$} \\
\hline & & Yes & No & -2 & -1 & 0 & +1 & +2 \\
\hline Camping at a developed site & & Yes & No & -2 & -1 & 0 & +1 & +2 \\
\hline Wilderness/backcountry day hiking & & Yes & No & -2 & -1 & 0 & +1 & +2 \\
\hline Environmental education programs & & Yes & No & -2 & -1 & 0 & +1 & +2 \\
\hline Boating/rafting/canoeing & & Yes & No & -2 & -1 & 0 & +1 & +2 \\
\hline Picnicking & & Yes & No & -2 & -1 & 0 & +1 & +2 \\
\hline Swimming (not in a pool) & & Yes & No & -2 & -1 & 0 & +1 & +2 \\
\hline Off-highway vehicle riding & & Yes & No & -2 & -1 & 0 & +1 & +2 \\
\hline Visiting interpretive centers & & Yes & No & -2 & -1 & 0 & +1 & +2 \\
\hline Visiting historic sites & & Yes & No & -2 & -1 & 0 & +1 & +2 \\
\hline
\end{tabular}


ALL

25. Now I'd like to ask you some further questions about your opinions of the recreation fee program. How much do you agree or disagree with each of the following statements. [Read each item, randomize list and rotate start]

\begin{tabular}{|c|c|c|c|}
\hline List of items by dimension: & 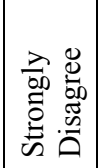 & 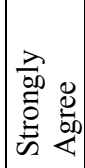 & 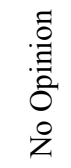 \\
\hline
\end{tabular}

Social Trust in the Forest Service

\begin{tabular}{|l|l|l|l|l|l|l|}
\hline I don't trust the FS to spend my fee dollars wisely. & 1 & 2 & 3 & 4 & 5 & -8 \\
\hline The Forest Service shares my values. & 1 & 2 & 3 & 4 & 5 & -8 \\
\hline The Forest Service has goals that are different from mine. & 1 & 2 & 3 & 4 & 5 & -8 \\
\hline
\end{tabular}

Fee Acceptance (general and program-specific)

\begin{tabular}{|l|l|l|l|l|l|l|}
\hline I understand the reasons behind the fee program. & 1 & 2 & 3 & 4 & 5 & -8 \\
\hline Overall, I approve of the Northwest Forest Pass program. & 1 & 2 & 3 & 4 & 5 & -8 \\
\hline There is nothing wrong with charging fees to recreate on National Forests. & 1 & 2 & 3 & 4 & 5 & -8 \\
\hline Fees should be used to make up for declining agency budgets. & 1 & 2 & 3 & 4 & 5 & -8 \\
\hline
\end{tabular}

Fee Equity

\begin{tabular}{|c|c|c|c|c|c|c|}
\hline $\begin{array}{l}\text { Charging fees on National Forests will make it so that only the rich can use } \\
\text { the best areas. }\end{array}$ & 1 & 2 & 3 & 4 & 5 & -8 \\
\hline $\begin{array}{l}\text { Fees are inappropriate because they may exclude some visitors from the } \\
\text { National Forest. }\end{array}$ & 1 & 2 & 3 & 4 & 5 & -8 \\
\hline $\begin{array}{l}\text { If someone can't afford to pay the fee, they shouldn't use the National } \\
\text { Forest. }\end{array}$ & 1 & 2 & 3 & 4 & 5 & -8 \\
\hline $\begin{array}{l}\text { People should be able to recreate on National Forests even if they can't } \\
\text { afford to pay the fee. }\end{array}$ & 1 & 2 & 3 & 4 & 5 & -8 \\
\hline $\begin{array}{l}\text { Everybody should pay the same fee regardless of income, ethnicity, family } \\
\text { size, disability, etc. }\end{array}$ & 1 & 2 & 3 & 4 & 5 & -8 \\
\hline
\end{tabular}

Personal Impact of Fees

\begin{tabular}{|l|l|l|l|l|l|l|}
\hline I can't afford to pay a fee to recreate on National Forests. & 1 & 2 & 3 & 4 & 5 & -8 \\
\hline The fee program limits my access to National Forest sites. & 1 & 2 & 3 & 4 & 5 & -8 \\
\hline I try to avoid National Forest sites that charge user fees. & 1 & 2 & 3 & 4 & 5 & -8 \\
\hline $\begin{array}{l}\text { I get less satisfaction from recreating on National Forests if I pay a fee to } \\
\text { use an area. }\end{array}$ & 1 & 2 & 3 & 4 & 5 & -8 \\
\hline
\end{tabular}

Fees and Taxes

\begin{tabular}{|c|c|c|c|c|c|c|}
\hline $\begin{array}{l}\text { I should not have to pay a fee to visit recreation sites because I already pay } \\
\text { enough taxes to support such areas }\end{array}$ & 1 & 2 & 3 & 4 & 5 & -8 \\
\hline $\begin{array}{l}\text { A greater percentage of my tax dollars should go towards conservation and } \\
\text { visitor services on public lands }\end{array}$ & 1 & 2 & 3 & 4 & 5 & -8 \\
\hline Recreation is a social good and should be supported by tax dollars & 1 & 2 & 3 & 4 & 5 & -8 \\
\hline Public lands are the birthright of Americans and should remain free & 1 & 2 & 3 & 4 & 5 & -8 \\
\hline
\end{tabular}


Fees and Information

Knowing that $80 \%$ of the revenue stays at the area where I pay the fee makes me more willing to pay entrance fees

Knowing why fees are charged makes me more willing to pay recreation fees

Knowing where and how the fee dollars are spent makes me more willing

to pay recreation fees

\begin{tabular}{|l|l|l|l|l|l|}
\hline 1 & 2 & 3 & 4 & 5 & -8 \\
\hline 1 & 2 & 3 & 4 & 5 & -8 \\
\hline 1 & 2 & 3 & 4 & 5 & -8 \\
\hline
\end{tabular}

Effectiveness of Fees

Charging fees helps the Forest Service do a better job at protecting the land while providing recreational opportunities

Fees are necessary to maintain the quality of services provided to the public

I will get better services and facilities if I pay user fees

\begin{tabular}{|l|l|l|l|l|l|}
\hline 1 & 2 & 3 & 4 & 5 & -8 \\
\hline 1 & 2 & 3 & 4 & 5 & -8 \\
\hline 1 & 2 & 3 & 4 & 5 & -8 \\
\hline
\end{tabular}

Fees and Efficiency (cost effectiveness)

\begin{tabular}{|l|l|l|l|l|l|l|}
\hline It costs less to manage National Forests with users fee than with taxes & 1 & 2 & 3 & 4 & 5 & -8 \\
\hline $\begin{array}{l}\text { It costs less to maintain recreation facilities and services with user fee than } \\
\text { with taxes }\end{array}$ & 1 & 2 & 3 & 4 & 5 & -8 \\
\hline $\begin{array}{l}\text { Charging fees creates healthy competition between providers of recreation } \\
\text { opportunities }\end{array}$ & 1 & 2 & 3 & 4 & 5 & -8 \\
\hline
\end{tabular}

Fees and the Public Relationship

\begin{tabular}{|l|l|l|l|l|l|l|}
\hline Fees make public land agencies more responsible to their visitors & 1 & 2 & 3 & 4 & 5 & -8 \\
\hline Fees disrupt the relationship between the public and public lands & 1 & 2 & 3 & 4 & 5 & -8 \\
\hline Charging fees on National Forests will lead to over-commercialization & 1 & 2 & 3 & 4 & 5 & -8 \\
\hline
\end{tabular}

Fees and Geographic Origin of Visitors

\begin{tabular}{|l|l|l|l|l|l|l|}
\hline Fees are unfair to the residents living close to National Forests & 1 & 2 & 3 & 4 & 5 & -8 \\
\hline Frequent visitors should get discounted fees & 1 & 2 & 3 & 4 & 5 & -8 \\
\hline
\end{tabular}

26. In your opinion, what is the proper balance between taxes and user fees for generating operating funds for public forest areas?

\begin{tabular}{c|c|c|c|c|c|}
$\begin{array}{c}\text { Entirely from } \\
\text { taxes }\end{array}$ & $\begin{array}{c}\text { Mostly from } \\
\text { taxes }\end{array}$ & $\begin{array}{c}\text { Equally from taxes } \\
\text { and user fees }\end{array}$ & \multicolumn{1}{c}{$\begin{array}{c}\text { Mostly from } \\
\text { user fees }\end{array}$} & $\begin{array}{c}\text { Entirely from } \\
\text { user fees }\end{array}$ & $\begin{array}{c}\text { Don't } \\
\text { know }\end{array}$ \\
\hline 1 & 2 & 3 & 4 & 5 & -8 \\
\hline
\end{tabular}

27. Suppose the National Forest did not have enough money or staff to adequately maintain a particular recreation site. Please tell us how much you support or oppose the following options.

\begin{tabular}{|c|c|c|c|c|c|c|}
\hline & 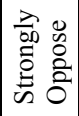 & & & & 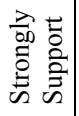 & خ. \\
\hline a. Impose a fee for people to use the site. & 1 & 2 & 3 & 4 & 5 & -8 \\
\hline b. Allow private corporations to sponsor the site. & 1 & 2 & 3 & 4 & 5 & -8 \\
\hline c. Keep the site open but allow it to deteriorate. & 1 & 2 & 3 & 4 & 5 & -8 \\
\hline d. Close the site for recreational use. & 1 & 2 & 3 & 4 & 5 & -8 \\
\hline $\begin{array}{l}\text { e. Contract with a private company to manage the } \\
\text { site }\end{array}$ & 1 & 2 & 3 & 4 & 5 & -8 \\
\hline
\end{tabular}

27a. Of the above options, what would be your first choice? 
27b. Do you have any other suggestions for how to maintain a recreation site if the government does not have enough funds to operate the site?

28. Please tell us how much you support or oppose the following management policies.

\begin{tabular}{|c|c|c|c|c|c|c|}
\hline & 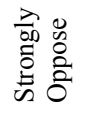 & & & & 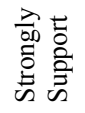 & خํ. \\
\hline $\begin{array}{l}\text { Set aside some areas of National Forests where no fees } \\
\text { are charged. }\end{array}$ & -2 & -1 & 0 & 1 & 2 & -8 \\
\hline Make one day a month free. & -2 & -1 & 0 & 1 & 2 & -8 \\
\hline $\begin{array}{l}\text { Do not charge fees for the use of National forest lands, } \\
\text { except for activities like camping at developed sites. }\end{array}$ & -2 & -1 & 0 & 1 & 2 & -8 \\
\hline Give low income visitors a free annual pass & -2 & -1 & 0 & 1 & 2 & -8 \\
\hline $\begin{array}{l}\text { Give people a free pass after they have volunteered and } \\
\text { worked at the site. }\end{array}$ & -2 & -1 & 0 & 1 & 2 & -8 \\
\hline Offer discounted fees to low income visitors & -2 & -1 & 0 & 1 & 2 & -8 \\
\hline Offer discounted fees to elderly visitors & -2 & -1 & 0 & 1 & 2 & -8 \\
\hline Offer discounted fees to disabled visitors & -2 & -1 & 0 & 1 & 2 & -8 \\
\hline Offer discounted fees to ethnic minorities & -2 & -1 & 0 & 1 & 2 & -8 \\
\hline Offer discounted fees to large families & -2 & -1 & 0 & 1 & 2 & -8 \\
\hline
\end{tabular}

29. People who wish to visit National Forest fee sites in Oregon and Washington currently have three choices for paying for those visits: pay a daily fee of $\$ 3.00$, purchase a Northwest Forest Pass which allows unlimited year-round visits to all fee sites in Oregon and Washington for $\$ 30$, or buy an interagency annual pass like the $\$ 65$ Golden Eagle or $\$ 10$ Golden Age passport, that allows unlimited year round visits to National Parks, National Forests and some other federally managed recreation areas. I'd like to ask you how you feel about each of these choices. All of the choices cover entrance fees for day use areas and facilities, but do not cover additional services such as overnight camping fees.

First of all, how do you feel about the amount of the fees within the current fee program? Regardless of whether you have purchased any of these passes, please give your response to each of the fee alternatives offered in the current fee program.

\begin{tabular}{|c|c|c|c|c|c|}
\hline Type of Pass & Way too low & Slightly too low & About right & Slightly too high & Way too high \\
\hline$\$ 3$ daily pass & ) & ) & ) & ( & ) \\
\hline$\$ 30$ Northwest Forest Pass & 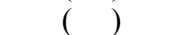 & ) & () & ()$^{\prime}$ & ) \\
\hline$\$ 65$ Golden Eagle Passport & ( ) & $(\quad)$ & ( ) & ( ) & ( ) \\
\hline$\$ 10$ Golden Age Passport & ( ) & ( ) & ( ) & ( ) & ( ) \\
\hline
\end{tabular}

30. Considering the daily pass, which covers the cost per vehicle for using a single fee area in the National Forests. Would you pay [\$3 \$4 \$5 \$6-randomly assigned] for this type of pass?

Do you think this is a fair price? Yes No

What is the maximum amount you would be willing to pay for this type of pass?

What do you think is the appropriate price to charge for such a pass? 
31. Next, considering the Northwest Forest Pass, which covers the cost per vehicle for using any National Forest day use sites or facilities in Oregon or Washington for a twelve-month period.

Would you pay [ $\$ 30 \$ 40 \$ 50 \$ 60$ - randomly assigned] for this type of pass? Yes No

Do you think this is a fair price? Yes No

What is the maximum amount you would be willing to pay for this type of pass?

What do you think is the appropriate price to charge for such a pass?

32. Finally, considering the Golden Eagle passport, which covers the cost per vehicle for using any National Forest, National Park, National Fish and Wildlife refuge, and Bureau of Land Management day use areas for a twelve-month period.

Would you pay [\$50 $\$ 65 \$ 75 \$ 100$ - randomly assigned] for this type of pass? Yes No

Do you think this is a fair price? Yes No

What is the maximum amount you would be willing to pay for this type of pass?

What do you think is the appropriate price to charge for such a pass?

33. Have you seen any tangible benefits from fees collected in the Oregon and Washington forests?

1 Yes

2 No

-8 Don't Know

Please list the benefits you have seen:

(INT: Record Answer Verbatim)

34. In your opinion, has the Forest Service been able to improve the quality

of recreation *services* due to funding from recreation fees?

1 Yes

2 No

-8 Don't Know

35. In your opinion, has the Forest Service been able to improve the quality

of recreation *facilities* due to funding from recreation fees?

1 Yes

2 No

-8 Don't Know 
36. How acceptable is it for the Forest Service to spend revenue from the fee program for the following services and facilities on National Forest recreation sites? [Circle one answer for each item]

\begin{tabular}{|c|c|c|c|c|c|c|}
\hline & 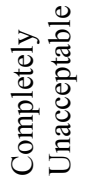 & & & & 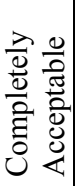 & $\begin{array}{l}\tilde{0} \\
0 \\
0 \\
0 \\
0 \\
0\end{array}$ \\
\hline Maintain the quality of the natural environment & -2 & -1 & 0 & 1 & 2 & $\mathrm{X}$ \\
\hline Maintain restrooms & -2 & -1 & 0 & 1 & 2 & $\mathrm{X}$ \\
\hline Improve security & -2 & -1 & 0 & 1 & 2 & $\mathrm{X}$ \\
\hline Maintain trails & -2 & -1 & 0 & 1 & 2 & $\mathrm{X}$ \\
\hline Provide recreation information & -2 & -1 & 0 & 1 & 2 & $\mathrm{X}$ \\
\hline $\begin{array}{l}\text { Provide assistance to insure access to recreation } \\
\text { opportunities for persons with disabilities }\end{array}$ & -2 & -1 & 0 & 1 & 2 & $\mathrm{X}$ \\
\hline Provide more recreation staff & -2 & -1 & 0 & 1 & 2 & $\mathrm{X}$ \\
\hline $\begin{array}{l}\text { Develop additional facilities, such as more trails } \\
\text { and trailheads }\end{array}$ & -2 & -1 & 0 & 1 & 2 & $\mathrm{X}$ \\
\hline Provide environmental education programs & -2 & -1 & 0 & 1 & 2 & $\mathrm{X}$ \\
\hline $\begin{array}{l}\text { Increase amenities at existing facilities such as } \\
\text { showers or electricity }\end{array}$ & -2 & -1 & 0 & 1 & 2 & $\mathrm{X}$ \\
\hline
\end{tabular}

37. Please let us know your priorities for spending your fees. Rank your top three priorities in order of importance to you with 1 being highest priority:

\begin{tabular}{|l|l|}
\hline $1-3$ & \multicolumn{1}{|c|}{ Priority } \\
\hline & Cleaner toilets \\
\hline & More toilets \\
\hline & Trail maintenance \\
\hline & More trails \\
\hline & Improving safety and security \\
\hline & More/better signage \\
\hline & More ranger presence \\
\hline & Maps and information \\
\hline & Fixing resource problems \\
\hline
\end{tabular}

\section{Finally, please tell us a little about yourself.}

ALL 38. What is your age?

ALL 39. Including yourself and your dependents, how many people live in your household? Number of people:

ALL 40. Do you have children under six years old living No Yes

ALL 41. Do you have children between 6 and 18 years old No Yes living with you? 
ALL 42. Which of the following best describes your occupation in the past year?

Full time student Employed full time Unemployed Homemaker/Caregiver
Part time student Employed part time Retired

Other

ALL 43. Which racial group(s) do you identify with? Check all that apply.
a. African American/Black
d. American Indian/ Alaska Native
b. Asian American
e. White
c. Native Hawaiian or other Pacific Islander
f. Other (please specify):

ALL 44. Are you Hispanic or Latino(a)?

No Yes

ALL 45. Which of the following reflects your total household income before taxes, for the last year?

\begin{tabular}{|c|c|c|c|}
\hline _Under $\$ 10,000$ & $\$ 50,001-70,000$ & $\$ 110,001-130,000$ & Over $\$ 170,000$ \\
\hline$\$ 10,001-30,000$ & $\$ 70,001-90,000$ & $\$ 130,001-150,000$ & \\
\hline$\$ 30,001-50,000$ & $\$ 90,001-110,000$ & $\$ 150,001-170,000$ & \\
\hline
\end{tabular}

ALL 46. What is the highest level of schooling you have completed?
a. Less than $9^{\text {th }}$ grade
e. Associates degree
b. $9^{\text {th }}$ grade to $12^{\text {th }}$ grade, no diploma
f. Bachelor's degree
c. High school graduate
g. Graduate or professional degree
d. Some college, no degree

ALL 47. Do you or does anyone in your household have a disability? Yes, respondent has a disability Yes, someone else in the household has a disability What is his/her relationship to you? No, there is no person with a disability in the household

IF YES:

How long have you (or the person in household w/ the disability) had the disability? number of years number of months

What is the formal/medical name of the disability?

Please provide a general description of the disability:

Does the disability hamper your/his/her ability to recreate in National Forests in Oregon or Washington? Yes No

If yes, what types of barriers have you (or the person in household $\mathrm{w} /$ the disability) experienced as a recreationist on an Oregon/Washington National Forest that are related to the disability?

\section{Barrier}

a. Facility accessibility

b. Trail accessibility

Individual program accessibility

d. Attitudinal- from FS employees

e. Attitudinal- from other visitors

f. Other

\section{Check all that apply}

Please describe:

Please describe:

Please describe:

Please describe:

Please describe:

Please describe: 
Is there a person or something internal that motivates you to recreate in National Forests in Oregon or Washington as a person with a disability?

Yes_ No

If yes, please tell us who/what this is and describe how you are motivated to participate:

Are there accommodations or is there assistance we could offer that would be helpful to you or anyone in your household to improve your recreational experience as a person with a disability? Yes No

If yes, please provide your suggestions:

If you would like to be interviewed to provide further information about accessibility in national parks for people with disabilities, may we contact you again? Yes No

ALL 48. What is your zip code?

ALL 49. Do you consider yourself to be currently living in an urban, suburban or rural area? Urban Suburban

Rural

ALL 50. Interviewer: record gender of respondent. Male Female

\section{Thank You for Your Participation in This Study!}

